\title{
EVALUATIONS OF PROCEDURAL JUSTICE: EVIDENCE OF GROUP- VALUE ISSUE INFLUENCE IN A PLANNING CONTEXT
}

\author{
A Thesis \\ presented to \\ the Faculty of California Polytechnic State University, \\ San Luis Obispo
}

In Partial Fulfillment

of the Requirements for the Degree

Master of City and Regional Planning

by

Thomas Wesley Hooper

March, 2010 
(C) 2010

Thomas Wesley Hooper

ALL RIGHTS RESERVED 


\section{COMMIT'TEE MEMBERSHIP}

TITLE:

AUTHOR:

DATE SUBMITTED:

COMMITTEE CHAIR:

COMMITTEE MEMBER:

COMMITTEE MEMBER:
Evaluations of Procedural Justice: Evidence of Group-value Issue Influence in a Planning Context

Thomas Wesley Hooper

March, 2010

Michael Boswell, Associate Professor

Michael Multari, Lecturer

Chris Clark, Lecturer 


\begin{abstract}
Evaluations of Procedural Justice: Evidence of Group-value Issue Influence in a Planning Context

Thomas Wesley Hooper
\end{abstract}

Justice research in the field of social psychology has focused primarily on situations involving legal proceedings, dispute resolution, and hierarchal relationships within organizations. This study extends the work of social psychologist Tom Tyler and others to a planning context by demonstrating that participants in a planning process use group-value criteria in addition to control over decisions and decision making processes and the favorability of outcomes to define reactions to their experiences. While certain aspects of the case study from which survey interviews were conducted limited the ability to replicate specific results of the 1989 Tyler study used as a model for this analysis, the major suppositions were confirmed. The results indicate that the group-value issues of standing, trust, and neutrality explain more variance in participant judgments of procedural justice, distributive justice, affect toward officials and fairness of officials than do control or outcome favorability. The results also demonstrate the dominance of standing and trust over all other concerns in participant assessments of procedural and distributive justice and the fairness of officials. 


\section{Acknowledgments}

I'd like express my sincere gratitude to my wife Jenny whose hard work, love, and patience made this journey possible. Like everything we do, graduate school was a partnership - and she gave much more than her share to make it happen. And as with so many life changing decisions we've made together, I can't image how I could ever find the courage to take the chance and dance without her support. 


\section{TABLE OF CONTENTS}

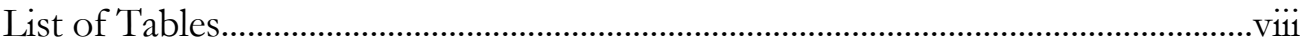

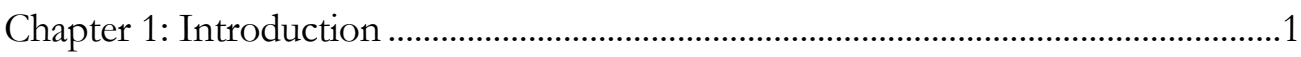

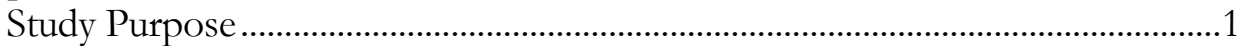

Supposition that Participants in a Planning Process will be More Concerned with Group-value Issues than with the Favorability of the Outcome or Control over Decisions and Decision Making Process

Supposition that Participants in a Planning Process will be More Concerned with Standing and, to a Lesser Degree, Trust than with Neutrality or Non

Group-value Issues ................................................................................................

Relevance to the Profession of Planning................................................................

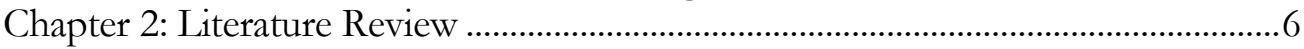

The Control Model of Procedural Justice ..............................................................6

The Group-Value or Relational Model...........................................................

Chapter 3: Case Study - The Los Osos Wastewater Facility Planning Process ....... 9

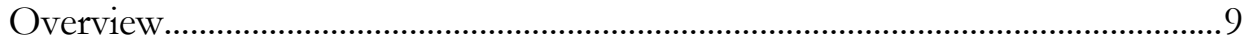

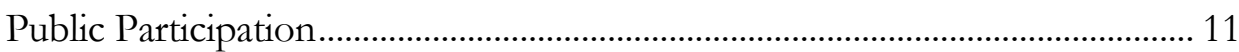

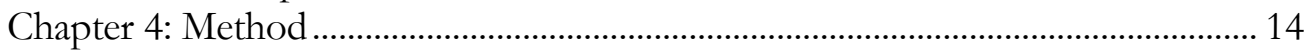

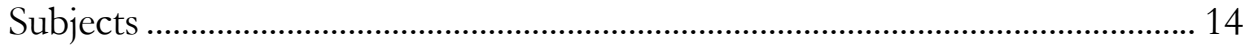

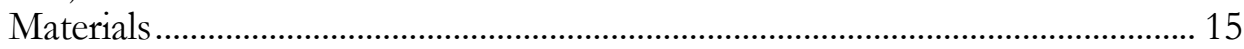

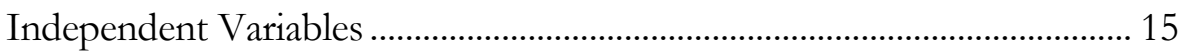

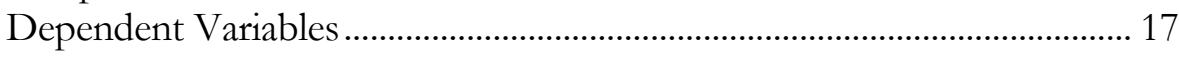

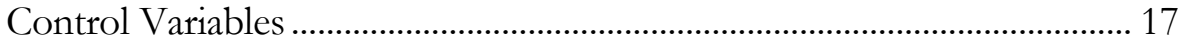

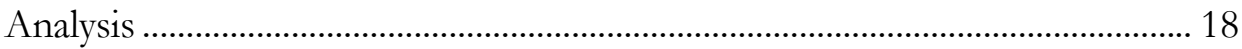

Descriptive Statistics to Determine Response Frequencies and Means, Correlations between Responses within Variable Groups, and Correlations between Independent Variables.................................................. 18

Regression Analysis to Determine the Degree of Dependant Variable

Variance that can be Attributed to Each Independent Variable................ 19

Regression Analysis to Determine the Magnitude Influence of Independent and Control Variables on Dependent Variables .................... 20 Regression Analysis to Determine the Magnitude Influence of Independent Variables on Procedural Justice - by Control Variable

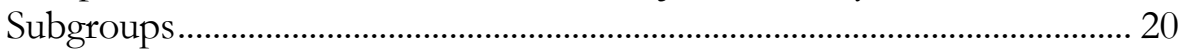

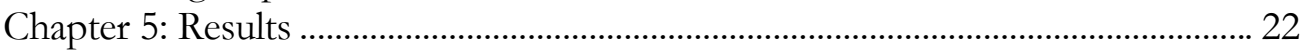

Response Frequencies, Means, and Correlations within Variable Groups \&

Correlations between Independent Variables........................................................ 22

The Degree of Dependant Variable Variance that can be Attributed to Each

Independent Variable ................................................................................................ 23 
The Magnitude Influence of Independent and Control Variables on Dependent Variables .............................................................................................. 24 The Magnitude Influence of Independent Variables on Judgments of Procedural Justice - by Control Variable Subgroups ............................................. 25

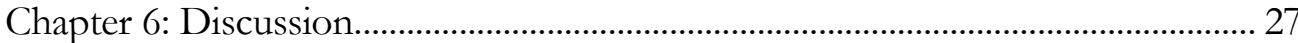
Support for the Group-value Model Interpretation and the Supposition that Participants in a Planning Process will be More Concerned with Group-value Issues than with the Favorability of the Outcome or Control over Decisions and Decision Making Process. 28 Support for the Supposition that Participants in a Planning Process will be More Concerned with Standing and, to a Lesser Degree, Trust than with Neutrality or Non Group-value Issues ........................................................... 29

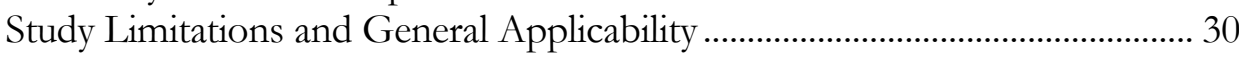

Practical Application of Findings ................................................................... 32

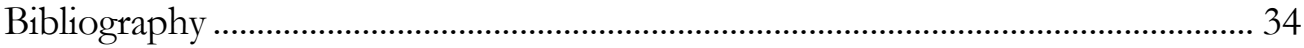

Appendix A: Public Perceptions Survey

Appendix B: Survey Response Frequencies and Means Appendix C: Correlations within Variable Groups Appendix D: Correlations between Control Variables \& between Control Variables and Independent Variables 


\section{List of Tables}

Number

1. Correlations between Independent Variables.

2. Degree of Dependent Variable Variance Explained by Independent Variables

3. Magnitude of Independent Variable Influence on Dependent Variables 25

4. Independent Variable Influence on Evaluations of Procedural Justice - by

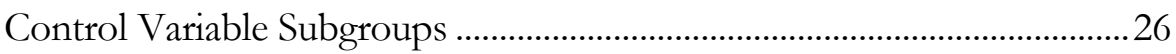





\section{Chapter 1}

Introduction

\section{Study Purpose}

In this study, I seek to extend the work of social psychologist Tom Tyler and others to a planning context by demonstrating that participants in a planning process will base their reactions to their experience on group-value issues in addition to the favorability of the outcome and control over the decision and decision making process. Of the three group-value issues, evidence that participants favor information regarding standing ${ }^{1}$ and trust ${ }^{2}$ would be particularly supportive of the group-value interpretation as they are most directly related to the group-value model and emphasis on neutrality ${ }^{3}$ can indicate either groupvalue and social exchange model influence (Tyler, 1989). Understanding how participants evaluate justice will help planners develop strategies for citizen involvement in planning processes that result in outcomes with broad public support.

Data used in this study was obtained through survey interviews with citizen participants in a planning process involving the Los Osos Community Services

1 Standing (or "status recognition") is "communicated by the interpersonal quality of treatment by the group and group authorities" and is measured by the extent to which people feel the authorities respect their rights, values and opinions; as well as the degree to which they have been treated politely and with dignity. It is a person's perception of their status within groups (Tyler, 1994, p.853).

2 Trust refers to a person's "belief that the intentions of third parties are benevolent." It is "the long-term nature of group membership that leads people to focus on the intentions of third parties." This includes inferences that authorities intend to treat people fairly and will work to serve the interests of all group members equally (Tyler, 1989, p.831).

3 Neutrality in authorities is measured as the extent to which they are honest, unbiased, and objective, using accurate information not influenced by opinion (Tyler, 1994). Because people view their relationship with authorities as long-term, they focus on information that provides evidence that suggests that, overtime, all group members will benefit equally from fair procedures and decision making (Tyler 1989). 
District in which plans for the development of a wastewater treatment facility in the town of Los Osos, California were discussed. Because the purpose of this study is to test the influence of group-value issues in a planning context, the survey questions and analysis method closely follow a study conducted by Tom Tyler as documented in his 1989 article in the Journal of Personality and Social Psychology titled, "The Psychology of Procedural Justice: A Test of the GroupValue Model." As the title suggests, the focus of research involving the groupvalue model has been how people evaluate procedural justice. However, in his 1989 study, Tyler was looking for evidence that people use information related to group-value issues in addition to control and outcome favorability to evaluate not just procedural justice, but also distributive justice, affect toward officials, and the fairness of officials. I chose the 1989 Tyler study as the "template" for this study because the broad range of dependent variables used will provide a more comprehensive understanding of how participants in a planning process define their experience.

This study deviates from the Tyler study in some instances to rephrase questions in a way that is better suited to the context of the case study and also to provide additional analysis where value is added. Departures from the Tyler study were kept to a minimum to reduce the possibility that factors not present in the Tyler study could influence the outcome. This allows for a more direct comparison of the results. All significant deviations from the Tyler study are reported in the Method and Discussion sections below.

Supposition that Participants in a Planning Process will be More Concerned with Group-value Issues than with the Favorability of the Outcome or Control over Decisions and Decision Making Process

The group-value model attributes concern over long-term relationships with authorities as the driving factor in the reliance on group-value issues. I 
hypothesize that citizen participants in a planning process will be particularly concerned with group-value issues because of their strong sense of community; as demonstrated by their willingness to invest time and effort to be involved in a planning process. They are also likely to have a strong commitment to the institution of planning, as they will view their relationship with officials in shaping their community's future as an ongoing process.

This supposition is supported by the research of Tyler and Degoey who demonstrated an increased importance of group-value issues in evaluations of procedural justice by people with a strong sense of community (Tyler \& Degoey 1995).

Supposition that Participants in a Planning Process will be More Concerned with Standing and, to a Lesser Degree, Trust than with Neutrality or Non Groupvalue Issues

I further hypothesize that participants in a planning process will be more concerned with information related to standing and, to a lesser degree, trust than with neutrality or non group-value issues. Because planning in the public sector typically involves the regulation of land uses and the provision of services restricting private property development and shaping the character of communities over time - participants will be particularly focused on cues from planning officials that indicate their rights as property owners and citizens are respected and that they are considered valued members of the community whose input is important (standing). Because citizens will likely view their relationship with planning agency officials as ongoing, they will also be concerned with information that indicates the intent of the officials - i.e., that they will use their discretionary authority justly in the future and will continue to provide opportunities for meaningful participation in the decision making process (trust). 
There are several reasons why participants in a planning process would focus less on the neutrality of planning officials than on standing and trust. First, planning issues at the local agency level typically involve setting public policy and policy implementing regulations that are broad brush by design, and so are not likely to be viewed as deliberately favoring one group over another. Second, while planning officials have discretionary authority to set policy and policy implementing regulations, they are mandated by law to do so in public session and allow public testimony; as well as conduct an environmental review process with public involvement for decisions that qualify as "projects" under the State or Federal Environmental Policy Acts. Since local agencies are governed by elected officials, public scrutiny serves to moderate any actions that could be construed as disproportionately favoring one group over another. This is unlike situations involving legal authorities in the Tyler study, where discretionary authority was exercised by non-elected officials to settle disputes and enforce laws set by policy makers who are subjected to political pressure.

\section{Relevance to the Profession of Planning}

Although the planning profession has evolved to recognize the benefits of involving the public on a meaningful level in the planning process, distrust of government institutions that emerged from the social unrest of the 1950s, 60s, and 70s continues today. Planners who seek to bridge the gap of trust between the institution they represent and the constituency they serve concern themselves with conducting planning processes that will be perceived as just by citizen stakeholders.

Although issues of social justice have become central to planning, justice research in the field of social psychology has focused primarily on situations involving legal proceedings, dispute resolution, and hierarchal relationships within organizations. Testing the influence of group-value issues in a planning context 
will provide professionals in the field and academia with a greater understanding of how citizen participants in a planning process evaluate justice. Because the business of public sector planning involves the regulation of land uses and the provision of services, residents are often very interested in participating in decision making processes to ensure that their interests are being served. As professionals motivated to implement plans designed to promote the orderly growth of communities, planners need to understand how public participants formulate justice judgments in order to maintain positive relationships with community members and garner support for initiatives. 
Chapter 2

Literature Review

The Control Model of Procedural Justice

Thibaut and Walker (1975) supported a resource-based model of justice that identified control over procedures and decisions as the primary elements people use to evaluate the fairness of procedures. A key aspect of the control theory is the assumption that people are primarily concerned with receiving favorable outcomes to disputes and that process control is valued only as a means to exert influence on distributive outcomes (Tyler 1994; Tyler 1989). However, their control model has been theorized to be somewhat limited to situations involving dispute resolution (Tyler, 1989) and subsequent studies suggest that people place emphasis on other criteria to assess procedural justice in circumstances outside of dispute resolution (Barret-Howard \& Tyler, 1996; Lissak \& Sheppard, 1983; Sheppard \& Lewicki, 1987; Sheppard, Sanders \& Minton, 1988; Tyler, 1988, as cited in Tyler, 1989).

Research by Thibaut and Walker assumed that people are primarily concerned with the outcome of a dispute and view their relationship with third party decision makers as short-term, driving them to value control over decisions. Subsequent research has suggested that decision control is actually secondary to process control in assessment of procedural justice and that the value people place on membership in groups causes them to view their relationship with institutions and authorities as long-term (Lind, Lissak \& Conlon, 1983; Tyler, 1987; Tyler, Rasinski \& Spodick, 1985, as cited in Tyler, 1989). 


\section{The Group-Value or Relational Model}

Through a series of independent studies and collaborative work with other researchers, Tom Tyler demonstrated the importance of standing, trust, and neutrality (collectively labeled "group-value" issues) in people's reactions to their experience with authorities. Group-value theory separated from previous work by researchers Thibaut and Walker which emphasized control over process and decisions in people's assessments of procedural justice. Group-value theory assumes that a person's concern over long-term relationships with authorities representing institutions drives a reliance on group-value issues to define procedural justice (Tyler 1989).

In 1989, Tom Tyler tested his group-value model of the psychology of procedural justice in a study examining citizen experiences with legal authorities. He affirmed his hypothesis that the group-value issues influence participant's evaluations of justice independent of the influence of the favorability of the outcome or control over decisions and the decision making process. Tyler asserts that standing is the strongest indicator of group-value issues, followed by trust and then neutrality (Tyler 1989). ${ }^{4}$

Lind and Tyler proposed the group-value model in 1988, later referred to as the relational model (Lind \& Tyler, 1992), to address how people assess procedural justice. The underlying assumption of the group-value model is that people value long-term membership in social groups such as institutions and that they use the fairness of their experience to gauge their status within these groups. Non-control

\footnotetext{
${ }^{4}$ In his 1989 study, Tyler states that evidence suggesting people "prefer information about their status in groups to favorable outcomes, that preference directly supports the group-value interpretation" (Tyler 1989, p.832). Evidence that people's trust in authorities is "being generalized to the group," supports the group-value interpretation - a person would only generalize their trust in authorities to the group if they viewed their interaction with the particular authorities as transient and their group membership as long-term (Tyler 1989, p.832). Reliance on the neutrality of authorities to assess fairness can be explained by both group-value and resource-based models of the psychology of procedural justice (Tyler 1989).
} 
issues of neutrality, trust, and standing are cited as the dominant means by which people assess procedural justice in their experiences with authorities in hierarchical organizations (Tyler, 1994).

In his 1989 research on group-value theory, Tyler found that standing and to a lesser degree trust, were the most important issues of those studied, lending support to his group-value model which hypothesized these to be stronger factors than neutrality and of greater importance than control issues in determining perceived procedural justice. Tyler also found that a person's level of commitment to the institutions represented by authorities positively influence their reliance on group-value issues to define procedural justice (Tyler, 1985; Tyler, 1994). In addition, Tyler and Degoey found in a 1995 study of procedural justice that respondents who had a strong sense of community were more likely to base perceptions of procedural justice on having "positive, relational bonds to the authorities than on the favorability of the authorities' decisions" (Tyler \& Degoey, 1995, p.482). 


$$
\text { Chapter } 3
$$

Case Study - The Los Osos Wastewater Facility Planning Process

\section{Overview}

Interaction between regulatory agencies and residents of Los Osos regarding local water quality and the need for wastewater treatment spanned five decades; beginning in the mid-1960s when test wells in the Los Osos valley showed increasing nitrates in a time period that included a doubling of residential water hookups. Studies conducted during the 1970s (a period where the environmental movement in California put increasing pressure on regulatory agencies to protect water resources) continued to recommend that septic tanks be replaced with a centralized treatment facility.

Prior to the creation of the Los Osos Community Services District (LOCSD) in 1998, the County of San Luis Obispo was responsible to the State of California for finding a solution to the wastewater treatment issue in Los Osos. During the 1980s, the County advocated for the implementation of a traditional gravity fed sewer system. Despite the prospect of federal Superfund dollars to cover $90 \%$ of the then $\$ 60$ million dollar cost, the citizens of Los Osos voted in 1983 against a tax to fund the project; which prompted the state Regional Water Board (RWB) to issue a Prohibition Area (Wolcott, 2009, p.34). The RWB resolution gave the citizens of Los Osos five years before a building moratorium would be invoked and the use of waste water drains in existing homes would be prohibited. In 1988, with the sewer project still not funded, the RWB imposed the building moratorium, but allowed continued use of water drains while the County worked toward an amicable solution.

In 1992 residents tried for a second time to form a CSD through citizen initiative (a previous effort failed to make the ballot in 1980 due to a lack of signatures), 
but the vote failed due to confusion over the text on the ballot in relation to a separate measure (Wolcott, 2009, p.46). During the 1990s, the County studied treatment options that deviated from the traditional sewer model. In 1996 the County proceeded with design of a system that utilized percolation ponds within Los Osos with the construction of a facility for primary and secondary treatment outside of the community (Wolcott, 2009, p.72). The County's actions at this point continued to satisfy the RWB that progress was being made and so no fines were levied; however, the building moratorium was still being enforced.

Citizens concerned about the location of the planned percolation ponds and the potential for additional costs due land acquisition formed the Taxpayers Against Percolation Ponds Site (TAPPS) and filed a lawsuit to appeal the Coastal Development Permit granted to the County by the California Coastal Commission (CCC). ${ }^{5}$ The CCC rescinded the permit and demanded additional study of alternatives in January of 1998. Frustrated by the delays and escalating costs, a group of residents formed the Solution Group (SG) to independently study alternatives. A technical review comparing the SG plan and the County plan indicated that the SG plan was more expensive, would not meet criteria to be eligible for low interest loans from the State Water Board (SWB) and would not likely achieve compliance with RWB regulations (Wolcott, 2009, p.82).

Inspired by the actions of a handful of their fellow residents in the SG, the citizens of Los Osos voted overwhelmingly to form a Community Services District in 1998 electing former SG members to all five Board of Directors positions (Wolcott, 2009, p.106). Shortly before the CSD election, the CCC voted to delay a decision on the coastal permit until the newly formed CSD had time to take control of planning for the sewer project. The CSD Board voted to

\footnotetext{
5 Additional land would be needed to accommodate construction of a treatment facility outside of town as well as for habitat conservation required by the United States Environmental Protection Agency as part of the construction of percolation ponds on the site in Los Osos where endangered snails were discovered.
} 
reject the County plan and advance the SG plan. The SG plan was rejected by the SWB and the needed low interest loan denied. The CSD ultimately advanced a plan that was similar to the original County plan in terms of cost and form after studying alternatives in earnest following the SWB decision.

The CCC voted to approve the coastal permit in 2001. By April 2004, all permits for the project had been approved and the construction contract was put out to bid. On April $15^{\text {th }}$, at the request of citizen activist groups, the CCC reversed their decision and agreed to suspend the permit while they reviewed the process under which the permit was originally issued. The CCC subsequently reissued the permit in August 2004 and the CSD went out to bid for a second time. The delay caused the community to lose a County grant and inflation and perceived risk on the part of the contractors caused the project construction cost to escalate to $\$ 118$ million dollars bringing the total cost of the project (including legal fees and study expenses) to $\$ 134$ million at the time the contract was awarded to the lowest bidder in early 2005 (Wolcott, 2009, p.183).

In 2006 the CSD filed for bankruptcy and the State Legislature voted to transfer responsibility for delivering the project from the CSD to the County. In October 2007, the citizens of Los Osos voted 80\% in favor of a tax to pay for the sewer project. The County conducted another study of alternatives and published an Environmental Impact Statement in March 2009. At the time of this writing, the sewer has not yet been constructed.

\section{Public Participation}

In the process of conducting research for her book "Small Town Perfect Storm," Barbara Wolcott reviewed over 18,000 pages of meeting minutes, reports, newspaper articles and relevant policy documents, but she writes that it was the 125 interviews of people involved in the controversial project that provided the most important information (Wolcott, 2009, p.7). She found that "no one, no 
matter how involved they were, had the whole picture" and that some were "in opposition at times" to the project (Wolcott, 2009, p.7). This speaks to the very long time-period over which this public process unfolded as well as to the high stakes, emotionally charged nature of the issue and the abundance of misinformation, distrust and animosity between factions of the community and regulatory agencies.

Wolcott describes a community divided into three camps: those who were for the traditional gravity fed sewer model originally proposed by the County and supported by the State regulatory agencies, those who supported exploring alternative wastewater treatment methods and those who opposed the construction of any type of treatment facility (Wolcott, 2009, p.82). The opinions of many community members shifted overtime as momentum for one position over another was influenced by the unfolding events. In turn, many community members became active participants for periods of time, affecting changes in public opinion - some serving as elected CSD Board members and hired staff and others devoting time and resources to various citizen activist groups. A very important aspect conveyed by Wolcott in her book is that due to the unusual circumstances cited above, residents developed unique perspectives informed, in part, by their circumstances and the timing and intensity of their involvement.

In considering the results of this study, it is important to note that the survey was sent to residents the week of April 5 ${ }^{\text {th }}, 2004$ - one week before the April $15^{\text {th }}$ CCC decision to suspend the coastal permit. The mailing list for the survey was generated from RWB and CSD meeting minutes and from letters written to those agencies and so provides a snapshot in time and captures a particular group of participants. In addition, many surveys were mailed to residents whose addresses or names were similar to incomplete information from those sources and so may have captured a subset of people who were active participants in other ways 
(through activists groups for example) or who may have been involved prior to the CSD formation. 
Method

\section{$\underline{\text { Subjects }}$}

A participant was defined as any citizen involved in the planning process at a minimum level; having either written a letter to the Los Osos Community Services District (LOCSD) or the Regional Water Quality Control Board (RWQCB) on the subject of the wastewater treatment plant, responded to a survey (by mail or phone) conducted by the LOCSD on the subject, or attended a LOCSD meeting where the wastewater treatment plant was discussed. Prospective interviewees were identified from the names and addresses contained in the minutes taken from public meetings held by the LOCSD and letters or responses to surveys received by the LOCSD and the RWQCB.

The survey (see Attachment A) was sent to over 150 households - 96 surveys were returned with varying degrees of completeness. ${ }^{6}$ An attempt was made to contact participants by phone before sending the survey. Letters were included with each survey explaining the study and requesting participation or reintroducing the study and expressing appreciation for participation (depending on whether or not the participant was reached ahead of time). ${ }^{7}$ Two weeks after

\footnotetext{
6 As is not uncommon, a number of returned surveys included questions that were left blank (indicated as a "non-response" in Appendix C). Regression analysis excluded surveys where any one of the variables in the equation did not have a value as a result of a non-response. Indexes created by averaging responses to two or more questions designed to measure a common characteristic were calculated based on the available data; i.e., an index created by averaging four questions where response values were 4, 2, blank, and blank, would have a value of 3 . The weighted absolute outcome favorability index was created by multiplying the recalibrated value of the response to the question measuring outcome favorability and the response to the question measuring the importance of the issue to the respondent and so a non-response to either of these questions resulted in a non-value for the index.

7 This survey uses a non-random method of identifying participants with a common experience and contacting as many as possible by mail. Subjects in the Tyler study were chosen at random from the City
} 
surveys were mailed, follow-up postcards were sent to participants to remind them to please complete and return the survey.

$\underline{\text { Materials }}$

Independent Variables

Outcome favorability A single question measured the absolute quality of the outcome by asking if the participant anticipated the outcome to be positive or negative (The survey was sent out before the final appeals decision of the Coastal Commission). ${ }^{8}$ In order to produce a more sensitive reading of the participant's assessment of the absolute quality of the outcome favorability, these responses were weighted by the self-reported importance of the issue. A set of four questions measured the relative quality of the outcome by asking participants to rate this experience in relation to other similar experiences, what their expectations were and if they were exceeded in a positive or negative way, and whether they thought other participants had a more positive or negative experience than themselves. The two questions related to expectations were found to not be correlated with each other and only one was correlated with the other two and so both were not considered for further analysis. The two remaining sets of responses were averaged to form a single outcome favorability (relative) index.

Control Respondent's perceived control over the process was measured by asking them how many opportunities they had to present their opinion before decisions were made. Asking respondents how much influence they had over the decisions that were made provided a gauge of decision control. Responses to the

of Chicago phone directory and interviewed over the phone. Subjects in the Tyler study were questioned regarding their varying experiences with legal authorities ( $22 \%$ had appearances in court, $47 \%$ made calls to police for help, and 31\% were stopped by police) (Tyler 1989).

8 See Appendix B for a complete listing of all questions considered for analysis and frequency and mean of responses (NOTE: not all questions in the sent survey were tested for correlation and considered for analysis.) 
two questions were found to be correlated, and so were averaged to form a single control index.

Neutrality Neutrality in authorities can be measured as a lack of bias and seeking out information in a good faith, objective manner. To assess lack of bias, respondents were asked if they thought the authorities acted in an unbiased manner. ${ }^{9}$ Respondents were asked whether officials had obtained the information they needed to make a good decision in order to assess their effort to make decisions based on facts. These responses were found to be correlated, and so were averaged to form a single neutrality index.

Trust Trust in authorities was measured in two ways. It was assessed directly by asking participants if they felt the actions of the officials were generally honest or dishonest. Another measure of trust was based on the respondent's perception of the intentions of authorities which was assessed by asking respondents to indicate how much effort officials had made to bring the problem into the open so it could be solved. ${ }^{10}$ These responses were found to be correlated, and so were averaged to form a single trust index.

Standing The measure of status conveyed from officials to participants was established by asking respondents whether officials had been polite to them and had shown them respect for their rights. These two measures were found to be correlated, and so were averaged to form a single standing index.

\footnotetext{
9 Bias was measured in the Tyler study by asking respondents "whether their treatment or outcome was influenced by their race, sex, age, nationality, or some other characteristic of them as a person", and in cases involving a dispute, "whether the legal authorities involved had favored one party over another." Tyler also measure neutrality as "propriety or impropriety of behavior" - measured by asking respondents "whether officials had lied" (Tyler 1989).

10 Trust was measured in the Tyler study by asking respondents to "indicate how much effort the authority had made to be fair to them" (Tyler 1989). Of the two questions used in this study to measure trust, one also measured participant perception of the level of effort officials made to solve problems in an open and fair manner, and the other asked for a direct assessment of the official's honesty - both are more similar to questions used in the Tyler study to measure neutrality as it relates to factual decision making.
} 


\section{Dependent Variables}

Fairness of Procedure To measure participant evaluations of procedural justice, the respondents were asked how fair the procedures used by officials were and how fairly they were treated. These two measures were found to be correlated, and so were averaged to form a single fairness of procedure index.

Fairness of Outcome To measure participant evaluations of distributive justice, respondents were asked about the fairness of the outcome and whether they had received what they deserved. These two measures were found to be correlated, and so were averaged to form a single fairness of outcome index.

Affect Toward Officials To measure participant feelings toward officials, respondents were asked to rate their level of anger, frustration and pleasure toward officials. These three measures were found to be correlated, and so were averaged to form a single affect toward officials index.

Fairness of Officials To measure participant beliefs about the justice of the officials, respondents were asked to indicate how fairly officials treat people and handle their problems, how often they treat people fairly, and how fairly they think that they would be treated if they were to deal with them in the future. These three measures were found to be correlated, and so were averaged to form a single fairness of officials index.

\section{Control Variables}

Commitment to Institution For the purpose of this study, commitment to the LOCSD (a planning agency or "institution") is equated to the level of support for the officials representing the planning agency. ${ }^{11}$ Respondents were asked two

11 The Tyler study measured respondents "commitment to the social group" using similar questions to measure support for authorities, but also asked questions to measured respondent's "obligation to obey legal authorities." This study did not measure an obligation to obey authority as it is not applicable to the case study. 
questions to measure their support for officials: 1) whether or not they feel proud of the LOCSD and 2) whether or not they respect the LOCSD. These measures were found to be correlated, and so were averaged to form a single commitment to institution index.

Level of Involvement Level of involvement was determined by asking respondents to indicate how many meetings they attended. If they were involved in some way other than attending meetings, they were asked to specify how. Four participants responded by indicating they had participated in ways other than meetings: "Committee representative for three years," "multiple reruns," "television broadcasts," and "verbal, follow in media, and acquaintance that is on Board" all four were coded as having the highest level of participation (equivalent to having attended more than 6 meetings).

Demographics Respondents were asked questions to determine factors of education, self-described political liberalism/conservatism, age, sex and ethnicity.

Date of Response This variable was established by assuming that if a survey response was received on or before April 16th, then it was completed and mailed before the Coastal Commission appeals decision was announced on April 15th.

Analysis

Descriptive Statistics to Determine Response Frequencies and Means, Correlations between Responses within Variable Groups, and $\underline{\text { Correlations between Independent Variables }}$

Survey response frequencies and means were not used to inform any direct study conclusions, but do provide valuable insight into the disposition and characteristics of the participants. Since responses were coded, standard deviations would not have been meaningful and so were not reported; however, it 
is important to note the distribution of responses across response choices as greater variance in responses will produce more robust results. Survey questions and response frequencies and means are reported in Appendix B.

Correlations between responses within variable groups (e.g., the group of responses measuring the independent variable standing) were used to determine which responses could be averaged to form single variable indexes. Correlations within variable groups are reported in Appendix C.

Correlation analysis was used to determine the degree of intercorrelation among independent variables. It is important to note the degree of intercorrelation among input variables as small changes in data values of highly interrelated independent variables may lead to large changes in coefficient values and less definitive results. Correlations between independent variables are reported in Table 1. Correlations between control variables as well as between control variables and independent variables are reported in Appendix D.

\section{Regression Analysis to Determine the Degree of Dependant Variable}

\section{Variance that can be Attributed to Each Independent Variable}

In order to understand the relative importance of group-value concerns, control and outcome favorability in participant assessments of various aspects of their experience in the planning process, a multiple regression analysis was conducted on each of the dependent variables with various combinations of independent variables. Analyzing the influence of each category of independent variables separately and then in addition to the other independent variable groups provides an indication of the influence of each group on the dependent variables in isolation, as well as the degree of influence above which can be explained by the other groups. $\mathrm{R}^{2}$ coefficients indicate the percentage of variance in the dependent variables that can be explained by the independent variable groups and are reported in Table 2. 


\section{Regression Analysis to Determine the Magnitude Influence of Independent and Control Variables on Dependent Variables}

A second type of multiple regression analysis was conducted to assess the magnitude of influence each independent variable had on the dependent variables. Under this analysis, all of the independent variables were entered into the regression equations simultaneously and their magnitude influence reported using beta weights expressed in standardized z-score form. Testing the influence of all independent variables simultaneously using a standardized coefficient allows for a direct comparison of the importance of each independent variable in participant assessments of their experience.

To evaluate the potential that the results reported in the beta weight regression analysis were influenced by one or more joint associations with third variables, each multiple regression analysis described above was repeated with the addition of all control variables representing situational and personal differences among the participants entered into the equation simultaneously with the independent variables. ${ }^{12}$ Results of this regression analysis are reported in Table 3.

\section{Regression Analysis to Determine the Magnitude Influence of Independent Variables on Procedural Justice - by Control Variable Subgroups}

A third type of multiple regression analysis was conducted to determine if different types of people, participants with varying experiences, and participants

\footnotetext{
12 Control variables for this portion of the analysis were limited to those targeting personal differences (demographics) and situational differences (level of involvement $\&$ if the survey was completed before or after the appeals decision) in order to determine if personal characteristics or variance in the type of experience influenced participant reaction to the experience. The control variable "commitment to institution" was excluded from consideration in this portion of analysis because it is a measure of a participant's feelings toward the institution represented by the officials and was designed to be used in the subgroup analysis as a test for evidence that those who are more committed to the group will place greater importance on group-value concerns in assessing procedural justice. Ethnicity was also excluded from this portion of the analysis because the lack of diversity among the participants $(86 \%$ of the participants were white) would have skewed the results.
} 
with differing levels of commitment to the institution assessed procedural justice differently. In this analysis, respondents were divided into subgroups representing each of the control variables. ${ }^{13}$ Regression analysis was run on the dependent variable "fairness of procedure" for each subgroup that included all independent variables entered simultaneously. As in the previous regression analysis, beta weights were used to determine the magnitude influence of each independent variable on the participant's assessment of procedural justice. The subgroup analysis of the control variable "commitment to institution" is of particular interest as greater reliance on group-value issues to define procedural justice in the more committed subgroup would provide further evidence for the group-value model effect. Results of this subgroup regression analysis are reported in Table 4.

\footnotetext{
13 The independent variable "absolute outcome favorability" was also divided into subgroups and tested because it represents a situational difference between participants.
} 
Chapter 5

Results

Response Frequencies, Means, and Correlations within Variable Groups \& Correlations between Independent Variables

Survey questions and response frequencies and means are reported in Appendix B. As stated in the Analysis section, no direct study conclusions were drawn from response frequencies and means, however; it is important to note that responses for all dependent variables and the vast majority of independent and control variables display a fairly uniform distribution across response choices. Prominent exceptions include: importance of the issue (91\% described the issue as "very important" or "important"), age of the participant ( $78 \%$ of respondents were 51 years or older), and ethnicity of the participant ( $86 \%$ of respondents were white).

Correlations within variable groups are reported in Appendix C. All responses within variable groups were found to be correlated with the exception of responses to two of the four questions within the variable group measuring relative outcome favorability.

Correlations between independent variables are reported in Table 1. All independent variables are highly correlated with Pearson correlation values ranging from $\mathrm{r}=.52$ to $\mathrm{r}=.87$ with $\mathrm{p}<.001$. 
Table 1: Correlations between Idependent Variables

\begin{tabular}{|c|c|c|c|c|c|c|c|}
\hline & & $\begin{array}{c}\text { IV-2.1 } \\
\text { Outcome } \\
\text { Favorability } \\
\text { (absolute) } \\
\text { INDEX }\end{array}$ & $\begin{array}{l}\text { IV-2.2 } \\
\text { Outcome } \\
\text { Favorability } \\
\text { (relative) } \\
\text { INDEX }\end{array}$ & $\begin{array}{l}\text { IV-3 } \\
\text { Control } \\
\text { INDEX }\end{array}$ & $\begin{array}{l}\text { IV-4 } \\
\text { Neutrality } \\
\text { INDEX }\end{array}$ & $\begin{array}{l}\text { IV-5 } \\
\text { Trust } \\
\text { INDEX }\end{array}$ & $\begin{array}{c}\text { IV-6 } \\
\text { Standing } \\
\text { INDEX }\end{array}$ \\
\hline \multirow{3}{*}{$\begin{array}{l}\text { IV-2.1 Outcome } \\
\text { Favorability } \\
\text { (absolute) INDEX }\end{array}$} & Pearson Correlation & ---- & --- & --- & --- & --- & --- \\
\hline & Sig. (2-tailed) & --- & --- & $-\cdots$ & --- & --- & --- \\
\hline & $\mathrm{N}$ & $\cdots$ & --- & --- & --- & ---- & -- \\
\hline \multirow{3}{*}{$\begin{array}{l}\text { IV-2.2 Outcome } \\
\text { Favorability } \\
\text { (relative) INDEX }\end{array}$} & Pearson Correlation & 0.595 & --- & $-\cdots-$ & --- & --- & --- \\
\hline & Sig. (2-tailed) & 0.000 & --- & --- & --- & ---- & $\ldots$ \\
\hline & $\mathrm{N}$ & 91 & --- & --- & --- & --- & --- \\
\hline \multirow{3}{*}{$\begin{array}{l}\text { IV-3 Control } \\
\text { INDEX }\end{array}$} & Pearson Correlation & 0.784 & 0.572 & $-\cdots-$ & --- & ---- & --- \\
\hline & Sig. (2-tailed) & 0.000 & 0.000 & --- & --- & --- & --- \\
\hline & $\mathrm{N}$ & 91 & 92 & --- & --- & ---- & --- \\
\hline \multirow{3}{*}{$\begin{array}{l}\text { IV-4 Neutrality } \\
\text { INDEX }\end{array}$} & Pearson Correlation & 0.755 & 0.511 & 0.772 & --- & ---- & -- \\
\hline & Sig. (2-tailed) & 0.000 & 0.000 & 0.000 & --- & --- & --- \\
\hline & $\mathrm{N}$ & 92 & 93 & 93 & --- & --- & -- \\
\hline \multirow[t]{3}{*}{ IV-5 Trust INDEX } & Pearson Correlation & 0.817 & 0.513 & 0.737 & 0.818 & --- & -- \\
\hline & Sig. (2-tailed) & 0.000 & 0.000 & 0.000 & 0.000 & --- & --- \\
\hline & $\mathrm{N}$ & 91 & 92 & 93 & 93 & --- & -- \\
\hline \multirow{3}{*}{$\begin{array}{l}\text { IV-6 Standing } \\
\text { INDEX }\end{array}$} & Pearson Correlation & 0.763 & 0.565 & 0.758 & 0.746 & 0.829 & --- \\
\hline & Sig. (2-tailed) & 0.000 & 0.000 & 0.000 & 0.000 & 0.000 & --- \\
\hline & N & 92 & 93 & 94 & 94 & 94 & --- \\
\hline
\end{tabular}

The Degree of Dependant Variable Variance that can be Attributed to Each Independent Variable

Table 2 reports $\mathrm{R}^{2}$ coefficients indicating the percentage of variance in dependent variables that can be explained by independent variable groups. In all four cases, the group-value issues of standing, trust, and neutrality explain more variance in participant judgments of procedural justice, distributive justice, affect toward officials, and fairness of officials than do control or the favorability of the outcome. This finding is true whether they are considered alone or in addition to other variables. When entered in the regression equation alone, group-value issues explain at least $7 \%$ more variance and as much as $27 \%$ more variance in dependent variables than control or outcome favorability and explain from three to sixteen times more unique variance in the dependent variables than non groupvalue issues. 
Table 2: Degree of Dependent Variable Variance Explained by Independent Variables

\begin{tabular}{|c|c|c|c|c|c|c|c|c|}
\hline \multirow[b]{3}{*}{ Independent Variable } & \multicolumn{8}{|c|}{ Dependent Variable } \\
\hline & \multicolumn{2}{|c|}{ Procedural Justice } & \multicolumn{2}{|c|}{ Distributive Justice } & \multicolumn{2}{|c|}{ Affect Toward Officials } & \multicolumn{2}{|c|}{ Fairness of Officials } \\
\hline & $\begin{array}{c}\text { Alone } \\
(\%)\end{array}$ & $\begin{array}{c}\text { Unique } \\
(\%)\end{array}$ & $\begin{array}{c}\text { Alone } \\
(\%)\end{array}$ & $\begin{array}{c}\text { Unique } \\
(\%)\end{array}$ & $\begin{array}{c}\text { Alone } \\
(\%)\end{array}$ & $\begin{array}{c}\text { Unique } \\
(\%)\end{array}$ & $\begin{array}{c}\text { Alone } \\
(\%)\end{array}$ & $\begin{array}{c}\text { Unique } \\
(\%)\end{array}$ \\
\hline \multicolumn{9}{|l|}{ Absolute and Relative } \\
\hline Outcome Favorability & $60 \%$ & $1 \%$ & $43 \%$ & $0 \%$ & $67 \%$ & $3 \%$ & $46 \%$ & $2 \%$ \\
\hline Control & $53 \%$ & $2 \%$ & $31 \%$ & $1 \%$ & $49 \%$ & $-1 \%$ & $48 \%$ & $1 \%$ \\
\hline Group-Value Issues & $73 \%$ & $11 \%$ & $58 \%$ & $16 \%$ & $74 \%$ & $9 \%$ & $78 \%$ & $27 \%$ \\
\hline Total & $76 \%$ & & $58 \%$ & & $76 \%$ & & $79 \%$ & \\
\hline
\end{tabular}

The Magnitude Influence of Independent and Control Variables on Dependent $\underline{\text { Variables }}$

Table 3 reports beta weights indicating the magnitude influence of each independent and control variable on the dependent variables. The results demonstrate the dominance of standing and trust over all other concerns, in all cases (the one exception is participant affect toward officials where standing was not statistically significant). Standing was more important than trust in participant assessments of procedural and distributive justice and fairness of officials; and trust was more important than all other concerns in participant affect toward officials where neutrality and absolute outcome favorability were almost as important as trust. Neutrality was also more important than non group-value concerns in participant assessments of the fairness of officials.

The addition of control variables measuring personal and situational differences had little significant effect on the beta weights of independent variables that were statistically significant in both the with and without third variable controls tests. 


\begin{tabular}{|c|c|c|c|c|}
\hline \multirow[b]{2}{*}{ Independent Variable } & \multicolumn{4}{|c|}{ Dependent Variable } \\
\hline & Procedural Justice & Distributive Justice & Affect Toward Officials & Fairness of Officials \\
\hline & \multicolumn{4}{|c|}{ Without third variable controls } \\
\hline \multicolumn{5}{|l|}{ Outcome Favorability } \\
\hline Absolute & 0.10 & 0.09 & 0.28 * & $-0.18 *$ \\
\hline Relative & 0.12 & 0.14 & $0.12 *$ & -0.01 \\
\hline Control & $0.07 *$ & -0.22 & -0.11 & 0.00 \\
\hline \multicolumn{5}{|l|}{ Group-Value Issues } \\
\hline Neutrality & 0.02 & 0.08 & $0.22 *$ & $0.19 *$ \\
\hline Trust & $0.21 *$ & 0.37 * & $0.33 *$ & $0.33 *$ \\
\hline \multirow[t]{2}{*}{ Group Standing } & $0.45 *$ & $0.39 *$ & 0.15 & $0.56 *$ \\
\hline & \multicolumn{4}{|c|}{ With third variable controls } \\
\hline \multicolumn{5}{|l|}{ Outcome Favorability } \\
\hline Absolute & 0.07 & 0.19 & $0.32 *$ & -0.15 \\
\hline Relative & 0.12 & $0.23 *$ & $0.18 *$ & 0.03 \\
\hline Control & 0.07 & -0.19 & -0.16 & 0.06 \\
\hline \multicolumn{5}{|l|}{ Group-Value Issues } \\
\hline Neutrality & 0.02 & 0.08 & $0.21 *$ & 0.17 \\
\hline Trust & $0.26 *$ & 0.29 & 0.37 * & $0.29 *$ \\
\hline \multirow[t]{2}{*}{ Group Standing } & $0.45 *$ & 0.26 & 0.07 & $0.53 *$ \\
\hline & \multicolumn{4}{|c|}{ Control variable beta weights } \\
\hline Level of Involvement & -0.08 & 0.04 & 0.05 & -0.03 \\
\hline Education & 0.03 & 0.00 & 0.07 & $0.10 *$ \\
\hline Political Orientation & 0.09 & 0.05 & 0.02 & 0.03 \\
\hline Age & 0.01 & -0.09 & -0.11 & 0.01 \\
\hline Sex & -0.02 & 0.05 & 0.00 & -0.03 \\
\hline Date of Response & -0.01 & -0.01 & -0.01 & 0.02 \\
\hline
\end{tabular}

The Magnitude Influence of Independent Variables on Judgments of Procedural Justice - by Control Variable Subgroups

Table 4 reports the results of regression analysis comparing the influence of group-value issues, control, and outcome favorability on judgments of procedural justice between control variable subgroups. Of the control variables representing situational differences among participants (absolute outcome favorability, level of involvement, and date of response), standing was the only variable shown to be statistically significant across subgroups. Standing was slightly more important for those whose outcome was less favorable and had attended more meetings. Standing was comparatively of equal importance for those who mailed their survey responses before the CCC decision on the permit appeal and those who mailed survey responses after the CCC decision.

Of the control variables representing personal differences among participants (political orientation, level of education, ethnicity, age, and sex), standing was 
again the only statistically significant variable across any of the subgroups. In this case, standing was significantly more important to self reported conservative leaning respondents than liberals in assessments of procedural justice and was equally important to male and female respondents.

The subgroup analysis of participant level of commitment to the institution represented by officials yielded mixed results - none of which were statistically significant across subgroups.

\begin{tabular}{|c|c|c|c|c|c|c|c|c|c|c|}
\hline \multirow[b]{2}{*}{ Independent Variable } & \multicolumn{2}{|c|}{$\begin{array}{l}\text { Outcome Favorability } \\
\text { (absolute) }\end{array}$} & \multicolumn{2}{|c|}{ Level of Involvement } & \multicolumn{2}{|c|}{ Date of Response } & \multicolumn{2}{|c|}{ Level of Commitment } & \multirow{2}{*}{\multicolumn{2}{|c|}{ Variance Key }} \\
\hline & Low & High & $\begin{array}{l}4 \text { or Less } \\
\text { Meetings }\end{array}$ & $\begin{array}{l}5 \text { or More } \\
\text { Meetings }\end{array}$ & $\begin{array}{c}\text { Mailed } \\
\text { Before } \\
\text { Decision }\end{array}$ & $\begin{array}{l}\text { Mailed } \\
\text { After } \\
\text { Decision }\end{array}$ & Low & High & & \\
\hline Outcome Favorability & $\mathrm{n}=57$ & $n=36$ & $\mathrm{n}=34$ & $n=62$ & $n=34$ & $n=62$ & $n=54$ & $n=28$ & \multirow{4}{*}{\multicolumn{2}{|c|}{$\begin{array}{l}\text { Shading identifies the } \\
\text { magnitude variance for } \\
\text { each independent } \\
\text { variable within the split } \\
\text { control variable groups }\end{array}$}} \\
\hline Absolute & NA & NA & 0.04 & 0.12 & 0.13 & 0.08 & $0.22 *$ & 0.20 & & \\
\hline Relative & $0.25 *$ & 0.05 & 0.13 & 0.11 & 0.07 & 0.10 & 0.14 & 0.06 & & \\
\hline Control & 0.08 & -0.06 & -0.07 & 0.09 & 0.09 & 0.08 & 0.08 & -0.23 & & \\
\hline \multicolumn{3}{|l|}{ Group-Value Issues } & & & & & & & \multirow{4}{*}{\multicolumn{2}{|c|}{\begin{tabular}{|c|}
$0.05-0.1$ \\
$0.11-0.2$ \\
$0.21-0.3$ \\
$0.31+$
\end{tabular}}} \\
\hline Neutrality & -0.03 & 0.28 & 0.04 & 0.05 & -0.06 & 0.06 & -0.04 & 0.41 & & \\
\hline Trust & 0.20 * & 0.09 & $0.42 *$ & 0.08 & $0.38 *$ & 0.13 & 0.18 & -0.32 & & \\
\hline Group Standing & 0.49 * & $0.40 *$ & $0.46 *$ & $0.52 *$ & $0.44 *$ & $0.48 *$ & $0.43 *$ & 0.21 & & \\
\hline \multirow[b]{2}{*}{ Independent Variable } & \multicolumn{2}{|c|}{ Political Orientation } & \multicolumn{2}{|c|}{ Level of Education } & \multicolumn{2}{|c|}{ Ethnicity } & \multicolumn{2}{|c|}{ Age } & \multicolumn{2}{|c|}{ Sex } \\
\hline & Liberal & $\begin{array}{c}\text { Conser- } \\
\text { vative }\end{array}$ & $\begin{array}{c}\text { Associates } \\
\text { Degree \& } \\
\text { Lower }\end{array}$ & $\begin{array}{c}\text { Bachelor's } \\
\text { Degree \& } \\
\text { Higher }\end{array}$ & White & Other & 50 \& Under & Over 50 & Male & Female \\
\hline \multicolumn{7}{|l|}{ Outcome Favorability } & $n=21$ & $n=75$ & $n=51$ & $n=44$ \\
\hline Absolute & 0.12 & 0.40 & 0.09 & 0.09 & $0.16 *$ & NA & -0.24 & 0.14 & -0.06 & 0.23 \\
\hline Relative & $0.19 *$ & 0.18 & 0.16 & 0.06 & $0.09 *$ & -0.01 & -0.09 & $0.21 *$ & 0.17 & 0.13 \\
\hline Control & 0.03 & -0.15 & -0.38 & 0.12 & $0.15 *$ & 1.17 & 0.61 * & -0.07 & -0.05 & 0.13 \\
\hline \multicolumn{11}{|l|}{ Group-Value Issues } \\
\hline Neutrality & 0.15 & -0.14 & 0.11 & 0.08 & 0.02 & -4.33 & -0.33 & 0.02 & 0.03 & -0.01 \\
\hline Trust & 0.12 & -0.15 & 0.34 & $0.27 *$ & 0.15 & 1.26 & 0.67 & 0.18 & 0.35 * & 0.16 \\
\hline Group Standing & 0.44 * & $0.73 *$ & $0.55 *$ & $0.40 *$ & $0.49 *$ & 2.25 & 0.27 & 0.48 * & 0.49 * & $0.42 *$ \\
\hline
\end{tabular}

* Statistically significant at $p<.10$ 
Chapter 6

\section{Discussion}

Thibaut and Walker's control model is based in social exchange theory and suggests that people are primarily concerned with direct control over decisions and control over process as an indirect means of control over decisions in order to ensure favorable outcomes to disputes. Concern over process and decision control is assumed to be independent of and more important than the favorability of the outcome or the perceived fairness of the decision in people's judgments of procedural justice. Control theory also assumes that people are concerned with their long-term relationship with the party or parties with whom they have the dispute as opposed to the third party decision maker with whom their relationship is transitory (Tyler, 1989, 1994).

The group-value theory proposed by Lind and Tyler suggests it is concern over long-term relationships with third party decision makers or institutions represented by third parties that drives people to base judgments of procedural justice on issues related to this relationship in addition to the distribution of control or outcome favorability. Group-value theory assumes that people find group membership rewarding and that information regarding an individual's status within the group (or standing) is valued due to several factors including, but not limited to, an individual's need for emotional support, self validation, and the acquisition of material resources. People are also assumed to be concerned with trust in the benevolence of and the neutrality of authorities; primarily to ensure that equal treatment by authorities will result in an equitable distribution of resources over time (Tyler, 1989, 1994). 
Support for the Group-value Model Interpretation and the Supposition that Participants in a Planning Process will be More Concerned with Group-value Issues than with the Favorability of the Outcome or Control over Decisions and Decision Making Process

As Tyler noted in his 1989 study, evidence that people rely on information related to standing, trust, and neutrality to form reactions to their experiences with officials only supports the group-value model interpretation if it can be attributed to their concern over group membership and status. Of the three group-value concerns, standing is the most unique to the group-value model as evidence of a reliance on information communicated from the authorities indicating an individual's status within the group (being treated politely, respectfully, and with dignity, for example) can only be explained by the group-value model. Reliance on trust in authorities (or beliefs about authorities that form the basis for predictions of future behavior) to form judgments can only be directly attributed to the group-value theory if the subject believes their experience with the third party is transitory, as the third party is assumed to symbolize the group or institution. If the relationship with the third party is viewed as ongoing, then a reliance on trust to define their reaction to an experience could be explained by either the group-value or social exchange models. A focus on the neutrality of the third party can always be explained by either the group-value or social exchange models (Tyler 1989).

Consistent with the 1989 Tyler study, the findings of this study provide clear support for the group-value model interpretation in two ways. First, the groupvalue concerns of standing, trust, and neutrality were shown to explain variance in participant reactions to their experiences independent of control and outcome favorability. Second, standing and trust were shown to have a greater magnitude influence than all other issues across all four measures with the exception of affect toward officials where standing was not statistically significant. The fact 
that standing was particularly influential in participant assessments of procedural justice and fairness of officials provides very strong support for a group-value interpretation of the results.

In addition, group-value issues in both the 1989 Tyler study and this study were collectively more important than control or outcome favorability across all four measures (fairness of process, fairness of outcome, affect toward officials, and fairness of officials). While Tyler did not hypothesize that group-value issues would be more important than non group-value issues in participant reactions to their experiences (only that they would have an independent influence to that of control and outcome favorability), the fact that similar results have been reproduced in this study suggests that perhaps they are more important.

Support for the Supposition that Participants in a Planning Process will be More Concerned with Standing and, to a Lesser Degree, Trust than with Neutrality or Non Group-value Issues

As stated above, the findings of this study are generally consistent with the findings of the 1989 Tyler study (with the exception of the subgroup analysis of the variable "commitment to institution" - discussed below in the Study Limitations section). Participants in both studies generally favored information regarding standing and trust over all other issues. However the two studies differ in ways that support my supposition that participants in a planning process will place more importance on standing, and to a lesser degree trust, than on neutrality or non group-value issues.

Unlike the Tyler study where standing and trust were consistently of practically equal magnitude influence across all four measures, standing in the planning context had a much stronger magnitude influence than trust in participant assessments of procedural justice and fairness of officials. In both studies, neutrality was somewhat important in two of the four measures, but on average, 
much less important than standing and trust. These findings and the fact that neutrality in the planning context was only somewhat important in assessments of affect toward officials and fairness of officials, but not statistically significant in assessments of procedural and distributive justice, suggest something unique about how participants in this particular planning process, and perhaps planning processes in general, evaluate the fairness of their experience.

As discussed in further detail below in the Study Limitations section, the measure of participant affect toward officials may have been influenced by the perception that a majority of the officials (3 of 5 CSD Board members) strongly endorsed the wastewater treatment facility project; and so were, in the participants view, associated with the anticipated outcome. This could explain the increased importance of absolute outcome favorability and neutrality and the statistical insignificance of standing in comparison with the other three measures of participant reactions to their experiences. Putting this potential case study anomaly regarding affect toward officials aside, the other three measures, which deal with judgments of fairness (or justice), all display the anticipated pattern; with the exception of a modest concern over neutrality in assessments of the fairness of officials, which again could be due to the perceived association of the officials with the project.

\section{Study Limitations and General Applicability}

While the results of this analysis support my hypothesis that group-value concerns are more important criteria than control or outcome favorability in explaining participant reactions to their experience; the context of this particular planning process and the fact that the analysis involved a single case study, limited the scope of the analysis. For example, this study and the 1989 Tyler study both included a subgroup analysis comparing assessments of procedural justice across various situational differences between respondents. Of the seven 
situational differences analyzed in the Tyler study, Tyler found that control was a more important criterion for respondents involved in a dispute and for those whose outcome was unfavorable. This finding supports Tyler's supposition that Thibaut and Walker's control theory focused on control rather than group-value issues because they studied cases involving dispute resolution (Tyler 1989). The subgroup analysis in my study found a slight increase in the preference for control for respondents whose outcome was unfavorable, but respondents could not be divided among those involved in a dispute versus those not involved in a dispute because all of the participants were involved in the same planning process.

Another area where the ability to replicate the Tyler study may have been impacted by the context of the case study, involves the subgroup analysis of the variable "commitment to institution." The group-value model predicts that people who are more committed to the social group represented by authorities will place greater importance on group-value concerns and less on control over aspects of the procedure in their assessments of the fairness of a procedure (Tyler 1989). This analysis used two questions (similar to those used in the Tyler study) to measure respondent commitment to the Los Osos Community Services District (CSD): "Are you proud of the Los Osos CSD?" and "Do you respect the Los Osos CSD?" The results do not provide support for the group-value model interpretation. This may be due to the fact that the Los Osos CSD officials were in effect viewed as championing the wastewater treatment facility which was the subject of the planning process. ${ }^{14}$ As evidenced by the responses to the survey questions, as well as numerous newspaper articles and personal conversations with the participants, this issue was very emotionally charged with most

\footnotetext{
${ }^{14}$ The finding that the absolute favorability of the outcome was more important (and standing not statistically significant) in participant assessments of affect toward officials than in other aspects of their experience (see Table 3), provides some indication that participants associated their feelings toward officials with the project (or anticipated outcome).
} 
participants either strongly supporting or opposing the project. Strong, polarized feelings regarding the project, and the likely perception that the officials were intent on implementing the project, may have had unintended consequences regarding what the questions were actually measuring - i.e., the participants may have responded based on their feelings toward the officials perceived support of the project and their personal feelings toward the project rather than based on the their commitment to the institution as represented by the officials.

This case study is somewhat unusual in that participants were involved in the planning process at varying levels of intensity over a period spanning several decades. They were also very polarized in their opinions regarding the project and feelings about their experience as evidenced by the survey responses. However, the aspects of this case study that make it atypical do not influence the results of the analysis and so the findings can be extrapolated to other planning processes. These factors are irrelevant to the results because the study attempts to determine the relative importance of various criteria in participant assessments of justice and feelings toward officials rather than how they feel about the officials or if they received justice. Furthermore, although feelings and opinions among respondents were polarized, the survey results show that the sample is a balanced representation of the participant pool - i.e., the means of the majority of responses gravitate toward "neutral" while a high percentage of responses fall outside of neutral (see Appendix B).

\section{Practical Application of Findings}

The findings of this study indicate that participants in a planning process define justice primarily based on information that indicates their status (standing) within the group as communicated by officials and secondarily on information that indicates the benevolent intentions of those officials (trust). While participants do place some importance on the neutrality of officials, control over the process 
and decision, and the favorability of the outcome, these criteria are far less influential determinants of justice judgments.

A very important aspect of these finding for planning professionals is that people are assumed to care about their standing within the group and the trustworthiness of officials because they view their relationship with the institutions represented by the planning officials as long-term. People are looking for information that indicates their rights are being respected by officials they can trust in order to gain assurance that all community members will benefit equally (Tyler 1994). This is more important in participant evaluations of the fairness of the procedure, fairness of the outcome, and fairness of the officials than the favorability of the outcome of a particular process. And if participants view the proceedings and officials as being fair and judge the decision or outcome as fair, then they are much more likely to be supportive (or at least accepting) of the outcome or planning initiative - even if it does not favor them.

Another important aspect of standing is that people value membership in groups not only because they are concerned with equitable distribution of resources and privileges over time, but also because they are social beings who look to other group members (including officials) for validation of their opinions and attitudes and affirmation of their favorable status (Tyler 1989). Officials who engage the public in respectful dialog and provide opportunities for citizens to have meaningful input to decisions that affect the communities in which they live, not only gain the valuable insight of those who are often closest to the issues, but also validate that person's right to be heard and indicate to them that their knowledge and opinions are needed to arrive at the best possible outcome. 
Bibliography

Lind, E Allan \& Tyler, Tom. The Social Psychology of Procedural Justice. New York, NY: Plenum Press, 1988.

Thibaut, John \& Walker, Laurens. Procedural Justice. Hillsdale, NJ: Lawrence Erlbaum Associates Inc., 1975.

Tyler, Tom. \& Degoey, Peter. Collective Restraint in Social Dilemmas: Procedural Justice and Social Identification Effects on Support for Authorities. Journal of Personality and Social Psychology, (69): No. 3, 482-497, 1995.

Tyler, Tom. Governing Amid Diversity: The Effect of Fair Decision-making Procedures on the Legitimacy of Government. Law and Society Review, (28): 809-831, 1994.

Tyler, Tom. The Psychology of Procedural Justice: A Test of the Group-value Model. Journal of Personality and Social Psychology, (57): No. 5, 830-838, 1989.

Tyler, Tom. Why People Obey the Law: Procedural Justice, Legitimacy, and Compliance. New Haven, CT: Yale University Press, 1990.

Wolcott, Barbara. Small Town Perfect Storm. San Luis Obispo, CA: Central Coast Press, 2009. 


\section{Appendix A}

\section{Public Perceptions Survey}

Please choose the answer that mostly closely matches your desired response. Thank you for participating.

How important is the issue of the wastewater treatment plant to you?

$\begin{array}{ll} & \text { Very Important } \\ \text { _ Important } \\ \text { Neutral } \\ \text { - Unimportant } \\ \text { _ Very Unimportant }\end{array}$

Do you feel that the problem is close to being resolved? [NOTE: This question was included in the survey, but was rejected prior to analysis.]

Yes
- No

Assuming that plans will be completed as designed and scheduled, do you anticipate the outcome to be positive or negative?

Very Positive
Positive
Neutral
Negative
_ Very Negative

In comparison with other similar experiences you have had in the past, how do you view your experience participating in the planning process for the wastewater treatment facility.

Very Positive

Positive

Neutral

Negative

_ Very Negative
Did you anticipate that your experience would be positive or negative?

- Very Positive
- Positive
- Neutral
- Negative
_ Very Negative

Did your experience exceed your expectations in a positive or negative way?

Extremely Positively Exceeded My

Expectations

Positively Exceeded My Expectations

Matched My Expectations

Negatively Exceeded My Expectations

_ Extremely Negatively Exceeded My

Expectations

Do you think other participants generally had a more positive or negative experience than you?

_ Very Positive

Positive

Neutral

_ Negative

_ Very Negative

How many opportunities did you have to present your opinion before decisions were made?

Very Many Opportunities

_ Many Opportunities

_ Adequate Opportunities Few Opportunities Very Few Opportunities 
How much influence did you have over the decisions that were made?

Very Adequate Influence

Adequate Influence

Neutral

Inadequate Influence

_ Very Inadequate Influence

Did the Los Osos CSD act in an unbiased manner?

Very Unbiased

Unbiased

- Neutral

Biased

_ Very Biased

Did you interpret the actions of the Los Osos CSD officials to be generally honest or dishonest?
Very Honest
Honest
Neutral
Dishonest
Very Dishonest

Did Los Osos CSD officials obtain information adequate to make a good decision?
Very Adequate
Adequate
Neutral
Inadequate
_ Very Inadequate

Rate the effort put forth by Los Osos CSD officials try to bring the problem into the open so that it could be solved?

- Very Adequate
_ Adequate
_ Neutral
_ Inadequate
_ Very Adequate

Do you feel that the Los Osos CSD officials are typical of officials operating in a similar capacity in other communities? [NOTE: This question was included in the survey, but was rejected prior to analysis.]

_ Very Typical
Typical
Neutral
_ Untypical
_ Very Untypical

Were Los Osos CSD officials polite to you?

_ Very Polite
_ Polite
_ Neutral
— Impolite
_ Very Impolite

Did Los Osos CSD officials demonstrate respect for your rights as a citizen to participate, be informed, and voice your opinion?

Very Much Respect Given for Participation
Rights
— Much Respect Given for Participation Rights
- Adequate Respect Given for Participation
Rights
Little Respect Given for Participation Rights
— Very Little Respect Given for Participation
Rights


How fair was the procedure used by the Los Osos CSD officials?

$\begin{array}{ll} & \text { Very Fair } \\ \text { _ Fair } \\ \text { - Neutral } \\ \text { _ Unfair } \\ \text { _ Very Unfair }\end{array}$

How fairly were you treated by the Los Osos CSD officials?

_ Very Fair

- Fair

- Neutral

- Unfair

_ Very Unfair

Do you anticipate the outcome to be fair?

_ Very Fair

_ Fair

_ Neutral

- Unfair

— Very Unfair

Do you anticipate that you will receive what you deserve?

_ Strongly Agree

_ Agree

Neutral

_ Disagree

_ Strongly Disagree

Do you feel angry towards Los Osos CSD officials?

— Very Angry
— Angry
- Neutral
- Not Angry
_ Very Not Angry
Do you feel frustrated with Los Osos CSD officials?

_ Very Frustrated
Frustrated
_ Neutral
_ Unfrustrated
_ Very Unfrustrated

Do you feel pleased with Los Osos CSD officials?

_ Very Pleased

_ Pleased

- Neutral

- Displeased

_ Very Displeased

In general, how fairly did Los Osos CSD officials treat participants?

_ Very Fairly
_ Fairly
— Neutral
— Unfairly
— Very Unfairly

How often did Los Osos CSD officials treat people fairly?

- Very Often
- Often
- Neutral
- Infrequently
_ Very Infrequently 
How fairly would you expect to be treated by Los Osos CSD officials if you were to deal with them in the future?

_ Very Fairly

_ Fairly

Neutral

Unfairly

_ Very Unfairly

Are you proud of the Los Osos CSD?

_ Very Proud

- Proud

Neutral

Ashamed

_ Very Ashamed

Do you respect the Los Osos CSD?

_ Very Much Respect

_ Respect

- Neutral

Do Not Respect

_ Very Much Do Not Respect

How many Los Osos CSD meetings have you attended?

$-1-2$

$3-4$

5-6

More Than 6

_ Other Form of Participation

(Please Specify)
Please indicate the highest level of education you have completed.

High School

_ Associate's Degree

— Bachelor's Degree

_ Post-Graduate's Degree

Please indicate your political orientation.

_ Very Liberal

Liberal

Neutral

- Conservative

_ Very Conservative

Please indicate your age.

_ Below 21

- $21-30$

- $31-40$

$-41-50$

$-51-60$

- Over 60

Please indicate your sex.

Male
Female

Please indicate your primary ethnicity.

White

_ Hispanic or Latino

Black or African American

Asian

American Indian or Alaska Native

Native Hawaiian or other Pacific Islander

Other (Please Specify) 


\section{Appendix B}

Survey Response Frequencies \& Means

\section{Independent Variables}

IV-1.1 Importance

How important is the issue of the wastewater treatment plant to you?

\begin{tabular}{|c|c|c|c|c|}
\hline Code & Mean & Count & $\%$ & \\
\hline 5 & & 59 & 61 & _ Very Important \\
\hline 4 & 4.46 & 29 & 30 & _ Important \\
\hline 3 & & 1 & 1 & Neutral \\
\hline 2 & & 0 & 0 & _ Unimportant \\
\hline \multirow[t]{2}{*}{1} & & 5 & 5 & Very Unimportant \\
\hline & & 2 & 2 & No Response \\
\hline
\end{tabular}

IV-2.1 Outcome Favorability (absolute) Assuming that plans will be completed as designed and scheduled, do you anticipate the outcome to be positive or negative?

\begin{tabular}{|c|c|c|c|c|}
\hline Code & Mean & Count & $\%$ & \\
\hline 5 & \multirow{6}{*}{2.42} & 9 & 9 & _ Very Positive \\
\hline 4 & & 14 & 15 & _ Positive \\
\hline 3 & & 13 & 14 & _ Neutral \\
\hline 2 & & 28 & 29 & Negative \\
\hline \multirow[t]{2}{*}{1} & & 29 & 30 & _ Very Negative \\
\hline & & 3 & 3 & No Response \\
\hline
\end{tabular}

IV-2.2 Outcome Favorability (absolute) INDEX

NOTE: IV-2.1 was weighted by IV-1.1 to form a new outcome favorability (absolute) index.

\section{IV-2.21 Outcome Favorability (relative)} In comparison with other similar experiences you have had in the past, how do you view your experience participating in the planning process for the wastewater

\section{IV-2.22 Outcome Favorability (relative)} Did you anticipate that your experience would be positive or negative?

NOTE: Not correlated with IV-2.21, IV-2.23, or IV2.24 and so was not used in analysis. $\underline{\text { Code }} \frac{\text { Mean }}{2.45}$ Count $\stackrel{\%}{\longrightarrow}$

\begin{tabular}{|c|c|c|c|c|}
\hline Code & Mean & Count & $\%$ & \\
\hline 5 & \multirow{6}{*}{2.31} & 4 & 4 & _ Very Positive \\
\hline 4 & & 15 & 16 & _ Positive \\
\hline 3 & & 14 & 15 & _ Neutral \\
\hline 2 & & 28 & 29 & _ Negative \\
\hline \multirow[t]{2}{*}{1} & & 28 & 29 & _ Very Negative \\
\hline & & 7 & 7 & No Response \\
\hline
\end{tabular}

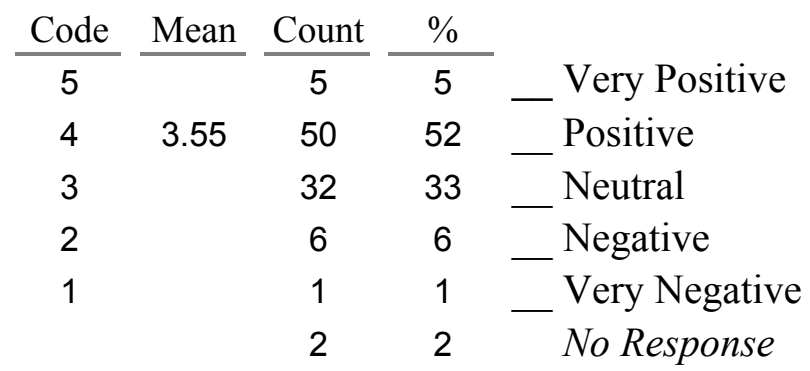




\begin{tabular}{|c|c|c|c|c|c|}
\hline \multirow{2}{*}{$\begin{array}{l}V-2.23 \text { Outcome Favorability (relative) } \\
\text { Did your experience exceed your } \\
\text { expectations in a positive or negative way? }\end{array}$} & Code & Mean & Count & $\%$ & \\
\hline & 5 & & 2 & 2 & $\begin{array}{l}\text { Extremely Positively } \\
\text { Exceeded My Expectations }\end{array}$ \\
\hline \multirow{6}{*}{$\begin{array}{l}\text { NOTE: Not correlated with IV-2.22 and so was not } \\
\text { used in analysis. }\end{array}$} & 4 & \multirow{6}{*}{2.14} & 7 & 7 & __ Positively Exceeded My \\
\hline & & & & & Expectations \\
\hline & 3 & & 19 & 20 & _ Matched My Expectations \\
\hline & 2 & & 37 & 39 & $\begin{array}{l}\text { Negatively Exceeded My } \\
\text { Expectations }\end{array}$ \\
\hline & 1 & & 26 & 27 & $\begin{array}{l}\text { Extremely Negatively } \\
\text { Exceeded My Expectations }\end{array}$ \\
\hline & & & 5 & 5 & No Response \\
\hline
\end{tabular}

\begin{tabular}{|c|c|c|c|c|c|}
\hline \multirow{7}{*}{$\begin{array}{l}I V-2.24 \text { Outcome Favorability (relative) } \\
\text { Do you think other participants generally } \\
\text { had a more positive or negative experience } \\
\text { than you? }\end{array}$} & Code & Mean & Count & $\%$ & \multirow{6}{*}{$\begin{array}{l}\text { — Very Positive } \\
\text { _ Positive } \\
\text { _ Neutral } \\
\text { — Negative } \\
\text { _ Very Negative }\end{array}$} \\
\hline & 5 & & 1 & 1 & \\
\hline & 4 & & 7 & 7 & \\
\hline & 3 & & 26 & 27 & \\
\hline & 2 & 2.33 & 41 & 43 & \\
\hline & 1 & & 14 & 15 & \\
\hline & & & 7 & 7 & No Response \\
\hline
\end{tabular}

\section{IV-2.2 Outcome Favorability}

(relative) INDEX

NOTE: IV-2.21 \& IV-2.24 were found to be

$\underline{\text { Code }} \frac{\text { Mean }}{2.34} \underline{\text { Count }} \stackrel{\%}{ }$

correlated, and so were averaged to form a new

outcome favorability (relative) index.

IV-3.1 Control (process)

How many opportunities did you have to present your opinion before decisions were made?

\section{IV-3.2 Control (decision)}

How much influence did you have over the decisions that were made?

\section{IV-3 Control INDEX}

NOTE: IV-3.1 \& IV-3.2 were found to be correlated, and so were averaged to form a new control index.

\begin{tabular}{|c|c|c|c|c|}
\hline Code & Mean & Count & $\%$ & \\
\hline 5 & \multirow{6}{*}{2.99} & 10 & 10 & _ Very Many Opportunities \\
\hline 4 & & 17 & 18 & __ Many Opportunities \\
\hline 3 & & 32 & 33 & __ Adequate Opportunities \\
\hline 2 & & 20 & 21 & Few Opportunities \\
\hline \multirow[t]{2}{*}{1} & & 9 & 9 & _ Very Few Opportunities \\
\hline & & 8 & 8 & No Response \\
\hline
\end{tabular}

\begin{tabular}{|c|c|c|c|c|}
\hline Code & Mean & Count & $\%$ & \\
\hline 5 & \multirow{6}{*}{2.12} & 3 & 3 & _ Very Adequate Influence \\
\hline 4 & & 13 & 14 & Adequate Influence \\
\hline 3 & & 13 & 14 & _ Neutral \\
\hline 2 & & 25 & 26 & _ Inadequate Influence \\
\hline \multirow[t]{2}{*}{1} & & 37 & 39 & _ Very Inadequate Influence \\
\hline & & 5 & 5 & No Response \\
\hline
\end{tabular}


IV-4.1 Neutrality (bias)

Did the Los Osos CSD act in an unbiased manner?

IV-4.2 Neutrality (factual)

Did Los Osos CSD officials obtain information adequate to make a good decision?

IV-4 Neutrality INDEX

NOTE: IV-4.1 \& IV-4.2 were found to be correlated, and so were averaged to form a new neutrality index.

IV-5.1 Trust

Did you interpret the actions of the Los Osos CSD officials to be generally honest or dishonest?

\section{IV-5.2 Trust}

Rate the effort put forth by Los Osos CSD officials try to bring the problem into the open so that it could be solved?

\begin{tabular}{|c|c|c|c|c|}
\hline Code & Mean & Count & $\%$ & \\
\hline 5 & \multirow{6}{*}{2.32} & 12 & 13 & _ Very Unbiased \\
\hline 4 & & 10 & 10 & _ Unbiased \\
\hline 3 & & 9 & 9 & Neutral \\
\hline 2 & & 28 & 29 & _ Biased \\
\hline \multirow[t]{2}{*}{1} & & 35 & 36 & _ Very Biased \\
\hline & & 2 & 2 & No Response \\
\hline
\end{tabular}

\begin{tabular}{|c|c|c|c|c|}
\hline Code & Mean & Count & $\%$ & \\
\hline 5 & \multirow{6}{*}{2.79} & 19 & 20 & _ Very Adequate \\
\hline 4 & & 12 & 13 & Adequate \\
\hline 3 & & 9 & 9 & _ Neutral \\
\hline 2 & & 33 & 34 & Inadequate \\
\hline \multirow[t]{2}{*}{1} & & 18 & 19 & Very Inadequa \\
\hline & & 5 & 5 & No Response \\
\hline
\end{tabular}

$\underline{\text { Code }} \frac{\text { Mean }}{2.55} \underline{\text { Count }} \stackrel{\%}{\longrightarrow}$

\begin{tabular}{|c|c|c|c|c|}
\hline Code & Mean & Count & $\%$ & \\
\hline 5 & \multirow{6}{*}{2.98} & 16 & 17 & _ Very Honest \\
\hline 4 & & 16 & 17 & _ Honest \\
\hline 3 & & 19 & 20 & _ Neutral \\
\hline 2 & & 32 & 33 & Dishonest \\
\hline \multirow[t]{2}{*}{1} & & 9 & 9 & Very Dishonest \\
\hline & & 4 & 4 & No Response \\
\hline
\end{tabular}

\begin{tabular}{|c|c|c|c|c|}
\hline Code & Mean & Count & $\%$ & \\
\hline 5 & \multirow{6}{*}{2.75} & 20 & 21 & _ Very Adequate \\
\hline 4 & & 13 & 14 & _ Adequate \\
\hline 3 & & 4 & 4 & _ Neutral \\
\hline 2 & & 36 & 38 & _ Inadequate \\
\hline \multirow[t]{2}{*}{1} & & 20 & 21 & _ Very Adequate \\
\hline & & 3 & 3 & No Response \\
\hline
\end{tabular}

$\underline{\text { Code }} \frac{\text { Mean }}{2.84} \underline{\text { Count }} \stackrel{\%}{\longrightarrow}$

\section{IV-5 Trust INDEX}

NOTE: IV-5.1 \& IV-5.2 were found to be correlated, and so were averaged to form a new trust index. 


\begin{tabular}{|c|c|c|c|c|c|}
\hline \multirow{7}{*}{$\begin{array}{l}I V-6.1 \text { Standing } \\
\text { Were Los Osos CSD officials polite to you? }\end{array}$} & Code & Mean & Count & $\%$ & \multirow{7}{*}{$\begin{array}{l}\text { - Very Polite } \\
\text { Polite } \\
\text { - Neutral } \\
\text { Impolite } \\
\text { - Very Impolite } \\
\text { No Response }\end{array}$} \\
\hline & 5 & & 23 & 24 & \\
\hline & 4 & & 22 & 23 & \\
\hline & 3 & 3.40 & 27 & 28 & \\
\hline & 2 & & 16 & 17 & \\
\hline & 1 & & 7 & 7 & \\
\hline & & & 1 & 1 & \\
\hline \multirow{7}{*}{$\begin{array}{l}I V-6.2 \text { Standing } \\
\text { Did Los Osos CSD officials demonstrate } \\
\text { respect for your rights as a citizen to } \\
\text { participate, be informed, and voice your } \\
\text { opinion? }\end{array}$} & Code & Mean & Count & $\%$ & \\
\hline & 5 & & 17 & 18 & $\begin{array}{l}\text { Very Much Respect Given } \\
\text { for Participation Rights }\end{array}$ \\
\hline & 4 & & 8 & 8 & $\begin{array}{l}\text { Much Respect Given } \\
\text { for Participation Rights }\end{array}$ \\
\hline & 3 & 2.79 & 18 & 19 & $\begin{array}{l}\text { Adequate Respect Given } \\
\text { for Participation Rights }\end{array}$ \\
\hline & 2 & & 31 & 32 & $\begin{array}{l}\text { Little Respect Given } \\
\text { for Participation Rights }\end{array}$ \\
\hline & 1 & & 15 & 16 & $\begin{array}{l}\text { Very Little Respect Given } \\
\text { for Participation Rights }\end{array}$ \\
\hline & & & 7 & 7 & No Response \\
\hline \multirow{2}{*}{$\begin{array}{l}I V-6 \text { Standing INDEX } \\
\text { NOTE: IV-6.1 \& IV-6.2 were found to be correlated, } \\
\text { and so were averaged to form a new standing index. }\end{array}$} & Code & Mean & Count & $\%$ & \\
\hline & & 3.13 & & & \\
\hline
\end{tabular}

\section{Dependent Variables}

DV-7.1 Fairness (procedure)

How fair was the procedure used by the Los Osos CSD officials?

DV-7.2 Fairness (procedure)

How fairly were you treated by the Los Osos CSD officials?

\begin{tabular}{|c|c|c|c|c|}
\hline Code & Mean & Count & $\%$ & \\
\hline 5 & \multirow{6}{*}{2.68} & 13 & 14 & Very Fair \\
\hline 4 & & 14 & 15 & Fair \\
\hline 3 & & 13 & 14 & _ Neutral \\
\hline 2 & & 28 & 29 & _ Unfair \\
\hline \multirow[t]{2}{*}{1} & & 20 & 21 & _ Very Unfair \\
\hline & & 8 & 8 & No Response \\
\hline Code & \multirow[t]{3}{*}{ Mean } & Count & $\%$ & \\
\hline 5 & & 18 & 19 & Very Fair \\
\hline 4 & & 15 & 16 & Fair \\
\hline 3 & \multirow[t]{4}{*}{3.13} & 29 & 30 & Neutral \\
\hline 2 & & 15 & 16 & Unfair \\
\hline \multirow[t]{2}{*}{1} & & 12 & 13 & Very Unfair \\
\hline & & 7 & 7 & No Response \\
\hline
\end{tabular}


$D V-7$ Fairness (procedure) INDEX

NOTE: DV-7.1 \& DV-7.2 were found to be correlated, and so were averaged to form a new fairness (procedure) index.

DV-8.1 Fairness (outcome)

Do you anticipate the outcome to be fair?

DV-8.2 Fairness (outcome)

Do you anticipate that you will receive what you deserve?

\section{DV-8 Fairness (outcome) INDEX}

NOTE: DV-8.1 \& DV-8.2 were found to be correlated, and so were averaged to form a new fairness (outcome) index.

DV-9.1 Affect Toward Officials

Do you feel angry towards Los Osos CSD officials?

$$
\underline{\text { Code }} \frac{\text { Mean }}{2.91} \text { Count } \stackrel{\%}{-}
$$

\begin{tabular}{|c|c|c|c|c|}
\hline Code & Mean & Count & $\%$ & \\
\hline 5 & \multirow{6}{*}{2.66} & 7 & 7 & _ Very Fair \\
\hline 4 & & 17 & 18 & Fair \\
\hline 3 & & 19 & 20 & _ Neutral \\
\hline 2 & & 27 & 28 & _ Unfair \\
\hline \multirow[t]{2}{*}{1} & & 17 & 18 & _ Very Unfair \\
\hline & & 9 & 9 & No Response \\
\hline
\end{tabular}

\begin{tabular}{|c|c|c|c|c|}
\hline Code & Mean & Count & $\%$ & \\
\hline 5 & \multirow{6}{*}{2.54} & 7 & 7 & _ Strongly Agree \\
\hline 4 & & 13 & 14 & Agree \\
\hline 3 & & 14 & 15 & _ Neutral \\
\hline 2 & & 33 & 34 & _ Disagree \\
\hline \multirow[t]{2}{*}{1} & & 16 & 17 & _ Strongly Disagree \\
\hline & & 13 & 14 & No Response \\
\hline
\end{tabular}

$\underline{\text { Code }} \frac{\text { Mean }}{2.61} \underline{\text { Count }} \stackrel{\%}{\longrightarrow}$

\begin{tabular}{|c|c|c|c|c|}
\hline Code & Mean & Count & $\%$ & \\
\hline 1 & \multirow{6}{*}{2.68} & 22 & 23 & _ Very Angry \\
\hline 2 & & 25 & 26 & _ Angry \\
\hline 3 & & 18 & 19 & _ Neutral \\
\hline 4 & & 12 & 13 & Not Angry \\
\hline \multirow[t]{2}{*}{5} & & 14 & 15 & _ Very Not Angry \\
\hline & & 5 & 5 & No Response \\
\hline
\end{tabular}

DV-9.2 Affect Toward Officials

Do you feel frustrated with Los Osos CSD

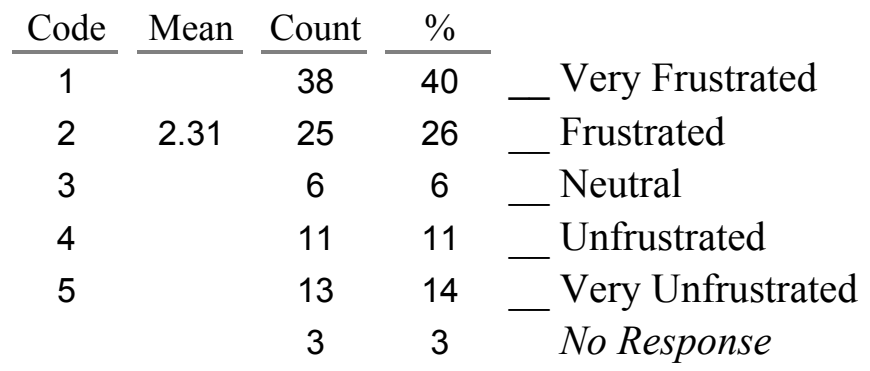


DV-9.3 Affect Toward Officials

Do you feel pleased with Los Osos CSD officials?

\begin{tabular}{|c|c|c|c|c|}
\hline Code & Mean & Count & $\%$ & \\
\hline 5 & \multirow{6}{*}{2.35} & 13 & 14 & _ Very Pleased \\
\hline 4 & & 9 & 9 & _ Pleased \\
\hline 3 & & 7 & 7 & _ Neutral \\
\hline 2 & & 33 & 34 & _ Displeased \\
\hline \multirow[t]{2}{*}{1} & & 31 & 32 & _ Very Displeasec \\
\hline & & 3 & 3 & No Response \\
\hline
\end{tabular}

$\underline{\text { Code }} \frac{\text { Mean }}{2.43} \underline{\text { Count }} \stackrel{\%}{ }$

NOTE: DV-9.1, DV-9.2, \& DV-9.3 were found to be correlated, and so were averaged to form a new affect toward officials index.

DV-10.1 Fairness (officials)

In general, how fairly did Los Osos CSD officials treat participants?

\begin{tabular}{|c|c|c|c|c|}
\hline Code & Mean & Count & $\%$ & \\
\hline 5 & \multirow{6}{*}{3.03} & 17 & 18 & _ Very Often \\
\hline 4 & & 16 & 17 & _ Often \\
\hline 3 & & 20 & 21 & _ Neutral \\
\hline 2 & & 23 & 24 & _ Infrequently \\
\hline \multirow[t]{2}{*}{1} & & 12 & 13 & Very Infrequently \\
\hline & & 8 & 8 & No Response \\
\hline
\end{tabular}

\begin{tabular}{|c|c|c|c|c|}
\hline Code & Mean & Count & $\%$ & \\
\hline 5 & \multirow{6}{*}{3.09} & 19 & 20 & _ Very Fairly \\
\hline 4 & & 15 & 16 & Fairly \\
\hline 3 & & 22 & 23 & Neutral \\
\hline 2 & & 27 & 28 & _ Unfairly \\
\hline \multirow[t]{2}{*}{1} & & 9 & 9 & Very Unfairly \\
\hline & & 4 & 4 & No Response \\
\hline
\end{tabular}

$\underline{\text { Code }} \frac{\text { Mean }}{2.92} \underline{\text { Count }} \stackrel{\%}{ }$
DV-10 Fairness (officials) INDEX

NOTE: DV-10.1, DV-10.2, \& DV-10.3 were found to be correlated, and so were averaged to form a new fairness (officials) index.
DV-10.2 Fairness (officials)

How often did Los Osos CSD officials treat people fairly?

\begin{tabular}{|c|c|c|c|}
\hline Mean & Count & $\%$ & \\
\hline \multirow{6}{*}{2.58} & 13 & 14 & _ Very Fairly \\
\hline & 11 & 11 & Fairly \\
\hline & 12 & 13 & Neutral \\
\hline & 33 & 34 & Unfairly \\
\hline & 21 & 22 & Very Unfairly \\
\hline & 6 & 6 & No Response \\
\hline
\end{tabular}

DV-10.3 Fairness (officials)

How fairly would you expect to be treated by Los Osos CSD officials if you were to deal with them in the future? 


\section{Control Variables}

CV-11.1 Commitment to Institution Are you proud of the Los Osos CSD?

\begin{tabular}{|c|c|c|c|c|}
\hline Code & Mean & Count & $\%$ & \\
\hline 5 & \multirow{6}{*}{2.59} & 18 & 19 & _ Very Proud \\
\hline 4 & & 3 & 3 & _ Proud \\
\hline 3 & & 17 & 18 & _ Neutral \\
\hline 2 & & 34 & 35 & Ashamed \\
\hline \multirow[t]{2}{*}{1} & & 22 & 23 & _ Very Ashamed \\
\hline & & 2 & 2 & No Response \\
\hline
\end{tabular}

CV-11.2 Commitment to Institution

Do you respect the Los Osos CSD?

\begin{tabular}{|c|c|c|c|c|}
\hline Code & Mean & Count & $\%$ & \\
\hline 5 & & 17 & 18 & _ Very Much Respect \\
\hline 4 & & 11 & 11 & _Respect \\
\hline 3 & 2.67 & 13 & 14 & _Neutral \\
\hline 2 & & 32 & 33 & __ Do Not Respect \\
\hline 1 & & 22 & 23 & _ Very Much Do Not Respect \\
\hline & & 1 & 1 & No Response \\
\hline
\end{tabular}

\section{CV-11 Commitment to Institution INDEX
NOTE: DV-11.1 \& DV-11.2 were found to be} correlated, and so were averaged to form a new commitment to institution index.

\section{CV-12.1 Level of Involvement}

How many Los Osos CSD meetings have you attended?

NOTE: The four responses describing other forms of participation were all determined to indicate a high level of engagement and so were coded as "4" - i.e., "More Than 6" meetings attended.

\section{CV-13 Demographics (education)}

Please indicate the highest level of education you have completed.

\begin{tabular}{|c|c|c|c|c|}
\hline Code & Mean & Count & $\%$ & \\
\hline 1 & \multirow{6}{*}{2.93} & 12 & 13 & $1-2$ \\
\hline 2 & & 22 & 23 & $3-4$ \\
\hline 3 & & 18 & 19 & $5-6$ \\
\hline \multirow[t]{3}{*}{4} & & 40 & 42 & _ More Than 6 \\
\hline & & 4 & 4 & $\begin{array}{l}\text { Other Form of Participation } \\
\text { (Please Specify) }\end{array}$ \\
\hline & & 0 & 0 & No Response \\
\hline
\end{tabular}

\begin{tabular}{|c|c|c|c|c|}
\hline Code & Mean & Count & $\%$ & \\
\hline 1 & \multirow{5}{*}{2.87} & 16 & 17 & __ High School \\
\hline 2 & & 14 & 15 & _Associate's Degree \\
\hline 3 & & 29 & 30 & _ Bachelor's Degree \\
\hline \multirow[t]{2}{*}{4} & & 34 & 35 & _ Post-Graduate's Degree \\
\hline & & 3 & 3 & No Response \\
\hline
\end{tabular}


CV-14 Demographics (political)

Please indicate your political orientation.

$$
\begin{array}{cccccl}
\text { Code } & \text { Mean } & \text { Count } & & \% & \\
\cline { 1 - 1 } & & 6 & 6 & & \text { - Very Liberal } \\
4 & & 37 & 39 & \text { - Liberal } \\
3 & 3.18 & 20 & 21 & \text { - Neutral } \\
2 & & 23 & 24 & \text { - Conservative } \\
1 & & 5 & 5 & \text { - Very Conservative } \\
& & 5 & 5 & \text { No Response }
\end{array}
$$

CV-15 Demographics (age)

Please indicate your age.

CV-16 Demographics (sex)

Please indicate your sex.

CV-17 Demographics (ethnicity)

Please indicate your primary ethnicity.

CV-18 Date Mailed

Was the survey response mailed before or after the Coastal Commission appeals decision of April 15?

NOTE: This was not a question on the survey -

\begin{tabular}{|c|c|c|c|c|}
\hline Code & Mean & Count & $\%$ & \\
\hline 6 & 5.81 & 83 & 86 & _ White \\
\hline 5 & & 2 & 2 & Hispanic or Latino \\
\hline 4 & & 0 & 0 & _ Black or African American \\
\hline 3 & & 1 & 1 & _ Asian \\
\hline 2 & & 3 & 3 & $\begin{array}{l}\text { American Indian or } \\
\text { Alaska Native }\end{array}$ \\
\hline 1 & & 0 & 0 & $\begin{array}{l}\text { Native Hawaiian or } \\
\text { other Pacific Islander }\end{array}$ \\
\hline & & 0 & 0 & _ Other (Please Specify) \\
\hline & & 7 & 7 & No Response \\
\hline
\end{tabular}
assumption was made that if it was received on or before April 16th, then it was mailed before the decision was announced.

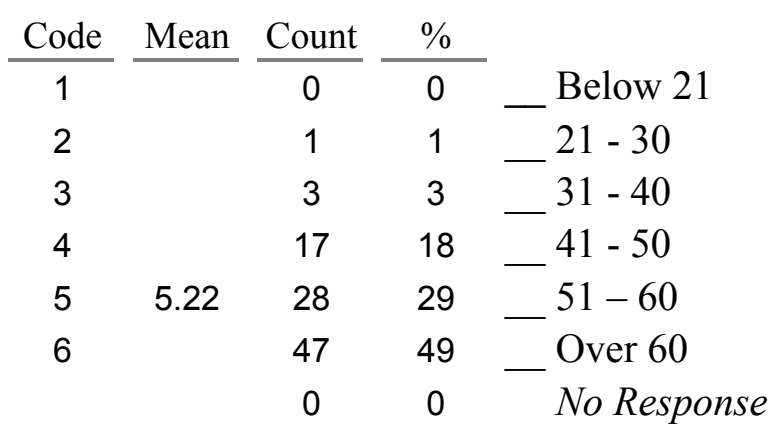

$\begin{array}{cccccll}\frac{\text { Code }}{1} & \text { Mean } & \text { Count } & & \% & & \\ 0.54 & 51 & & 53 & & \text { Male } \\ 0 & 44 & & 46 & & \text { Female } \\ & 1 & 1 & & \text { No Response }\end{array}$

$\begin{array}{cccccc}\frac{c}{1} & & \frac{\text { Mean }}{2} & \frac{\text { Count }}{34} & \frac{\%}{35} & \text { — Before } \\ 0 & 0.35 & 62 & 65 & \text { — After }\end{array}$




\section{Appendix C}

\section{Correlations within Variable Groups}

\begin{tabular}{|c|c|c|c|c|c|}
\hline Outcome Favorab & ity (relative) & $\begin{array}{c}\text { IV-2.21 } \\
\text { Outcome } \\
\text { Favorability } \\
\text { (relative) }\end{array}$ & $\begin{array}{c}\text { IV-2.22 } \\
\text { Outcome } \\
\text { Favorability } \\
\text { (relative) } \\
\text { NOT USED }\end{array}$ & $\begin{array}{c}\text { IV-2.23 } \\
\text { Outcome } \\
\text { Favorability } \\
\text { (relative) } \\
\text { NOT USED }\end{array}$ & $\begin{array}{l}\text { IV-2.24 } \\
\text { Outcome } \\
\text { Favorability } \\
\text { (relative) }\end{array}$ \\
\hline \multirow{3}{*}{$\begin{array}{l}\text { IV-2.21 Outcome } \\
\text { Favorability (relative) }\end{array}$} & Pearson Correlation & ---- & ---- & ---- & \\
\hline & Sig. (2-tailed) & -.-- & ---- & ---- & \\
\hline & $\mathrm{N}$ & ---- & ---- & --- & \\
\hline \multirow{3}{*}{$\begin{array}{l}\text { IV-2.22 Outcome } \\
\text { Favorability (relative) } \\
\text { NOT USED }\end{array}$} & Pearson Correlation & 0.129 & --- & --- & \\
\hline & Sig. (2-tailed) & 0.227 & ---- & ---- & \\
\hline & $\mathrm{N}$ & 89 & ---- & ---- & \\
\hline \multirow{3}{*}{$\begin{array}{l}\text { IV-2.23 Outcome } \\
\text { Favorability (relative) } \\
\text { NOT USED }\end{array}$} & Pearson Correlation & 0.785 & -0.049 & ---- & \\
\hline & Sig. (2-tailed) & 0.000 & 0.645 & ---- & \\
\hline & $\mathrm{N}$ & 87 & 91 & ---- & \\
\hline \multirow{3}{*}{$\begin{array}{l}\text { IV-2.24 Outcome } \\
\text { Favorability (relative) }\end{array}$} & Pearson Correlation & 0.282 & 0.060 & 0.216 & \\
\hline & Sig. (2-tailed) & 0.009 & 0.577 & 0.044 & \\
\hline & $\mathrm{N}$ & 85 & 88 & 87 & \\
\hline
\end{tabular}

\begin{tabular}{lrrr} 
Control & IV-3.1 & $\begin{array}{c}\text { IV-3.2 } \\
\text { Control } \\
\text { (process) }\end{array}$ & $\begin{array}{c}\text { Control } \\
\text { (decision) }\end{array}$ \\
\hline $\begin{array}{l}\text { IV-3.1 Control } \\
\text { (process) }\end{array}$ & Pearson Correlation & --- & --- \\
IV-3.2 Control & Sig. (2-tailed) & --- & --- \\
(decision) & $\mathrm{N}$ & --- & - \\
& Pearson Correlation & 0.563 & --- \\
\hline
\end{tabular}

IV-4.1 IV-4.2

\begin{tabular}{|c|c|c|c|}
\hline Neutrality & & $\begin{array}{l}\text { Neutrality } \\
\text { (bias) }\end{array}$ & $\begin{array}{c}\text { Neutrality } \\
\text { (factual) }\end{array}$ \\
\hline \multirow[t]{3}{*}{ IV-4.1 Neutrality (bias) } & Pearson Correlation & --- & --- \\
\hline & Sig. (2-tailed) & -.-- & --- \\
\hline & $\mathrm{N}$ & ---- & --- \\
\hline \multirow{3}{*}{$\begin{array}{l}\text { IV-4.2 Neutrality } \\
\text { (factual) }\end{array}$} & Pearson Correlation & 0.590 & --- \\
\hline & Sig. (2-tailed) & 0.000 & --- \\
\hline & $\mathrm{N}$ & 91 & - \\
\hline
\end{tabular}




\begin{tabular}{|c|c|c|c|c|}
\hline Trust & & $\begin{array}{l}\text { IV-5.1 } \\
\text { Trust }\end{array}$ & $\begin{array}{l}\text { IV } 5.2 \\
\text { Trust }\end{array}$ & \\
\hline \multirow[t]{3}{*}{ IV-5.1 Trust } & Pearson Correlation & --- & & --- \\
\hline & Sig. (2-tailed) & ---- & & - \\
\hline & $\mathrm{N}$ & ---- & & - \\
\hline \multirow[t]{3}{*}{ IV-5.2 Trust } & Pearson Correlation & 0.737 & & --- \\
\hline & Sig. (2-tailed) & 0.000 & & - \\
\hline & $\mathrm{N}$ & 91 & & --- \\
\hline \multicolumn{2}{|l|}{ Standing } & $\begin{array}{c}\text { IV-6.1 } \\
\text { Standing }\end{array}$ & $\begin{array}{c}\text { IV-6.2 } \\
\text { Standing }\end{array}$ & \\
\hline \multirow[t]{3}{*}{ IV-6.1 Standing } & Pearson Correlation & ---- & & --- \\
\hline & Sig. (2-tailed) & ---- & & --- \\
\hline & $\mathrm{N}$ & --- & & --- \\
\hline \multirow[t]{3}{*}{ IV-6.2 Standing } & Pearson Correlation & 0.865 & & --- \\
\hline & Sig. (2-tailed) & 0.000 & & ---- \\
\hline & $\mathrm{N}$ & 89 & & --- \\
\hline \multicolumn{2}{|l|}{ Fairness (procedure) } & $\begin{array}{c}\text { DV-7.1 } \\
\text { Fairness } \\
\text { (procedure) }\end{array}$ & $\begin{array}{c}\text { DV-7.2 } \\
\text { Fairness } \\
\text { (procedure }\end{array}$ & \\
\hline \multirow{3}{*}{$\begin{array}{l}\text { DV-7.1 Fairness } \\
\text { (procedure) }\end{array}$} & Pearson Correlation & --- & & --- \\
\hline & Sig. (2-tailed) & ---- & & --- \\
\hline & $\mathrm{N}$ & ---- & & --- \\
\hline \multirow{3}{*}{$\begin{array}{l}\text { DV-7.2 Fairness } \\
\text { (procedure) }\end{array}$} & Pearson Correlation & 0.751 & & --- \\
\hline & Sig. (2-tailed) & 0.000 & & ---- \\
\hline & $\mathrm{N}$ & 86 & & --- \\
\hline \multicolumn{2}{|l|}{ Fairness (outcome) } & $\begin{array}{c}\text { DV-8.1 } \\
\text { Fairness } \\
\text { (outcome) }\end{array}$ & $\begin{array}{c}\text { DV-8.2 } \\
\text { Fairness } \\
\text { (outcome) }\end{array}$ & \\
\hline \multirow{3}{*}{$\begin{array}{l}\text { DV-8.1 Fairness } \\
\text { (outcome) }\end{array}$} & Pearson Correlation & ---- & & --- \\
\hline & Sig. (2-tailed) & ---- & & --- \\
\hline & $\mathrm{N}$ & ---- & & --- \\
\hline \multirow{3}{*}{$\begin{array}{l}\text { DV-8.2 Fairness } \\
\text { (outcome) }\end{array}$} & Pearson Correlation & 0.695 & & --- \\
\hline & Sig. (2-tailed) & 0.000 & & ---- \\
\hline & $\mathrm{N}$ & 82 & & --- \\
\hline
\end{tabular}




\begin{tabular}{|c|c|c|c|c|c|}
\hline \multicolumn{2}{|c|}{ Affect Toward Officials } & $\begin{array}{c}\text { DV-9.1 } \\
\text { Affect } \\
\text { Toward } \\
\text { Officials }\end{array}$ & $\begin{array}{c}\text { DV-9.2 } \\
\text { Affect } \\
\text { Toward } \\
\text { Officials }\end{array}$ & $\begin{array}{c}\text { DV-9.3 } \\
\text { Affect } \\
\text { Toward } \\
\text { Officials }\end{array}$ & \multirow{10}{*}{ mean $r=0.83$} \\
\hline \multirow{3}{*}{$\begin{array}{l}\text { DV-9.1 Affect Toward } \\
\text { Officials }\end{array}$} & Pearson Correlation & --- & --- & $\overline{---}$ & \\
\hline & Sig. (2-tailed) & --- & --- & --- & \\
\hline & $\mathrm{N}$ & --- & --- & --- & \\
\hline \multirow{3}{*}{$\begin{array}{l}\text { DV-9.2 Affect Toward } \\
\text { Officials }\end{array}$} & Pearson Correlation & 0.828 & --- & --- & \\
\hline & Sig. (2-tailed) & 0.000 & ---- & ---- & \\
\hline & $\mathrm{N}$ & 90 & --- & ---- & \\
\hline \multirow{3}{*}{$\begin{array}{l}\text { DV-9.3 Affect Toward } \\
\text { Officials }\end{array}$} & Pearson Correlation & 0.867 & 0.806 & --- & \\
\hline & Sig. (2-tailed) & 0.000 & 0.000 & --- & \\
\hline & $\mathrm{N}$ & 90 & 91 & --- & \\
\hline \multicolumn{2}{|l|}{ Fairness (officials) } & $\begin{array}{l}\text { DV-10.1 } \\
\text { Fairness } \\
\text { (officials) }\end{array}$ & $\begin{array}{l}\text { DV-10.2 } \\
\text { Fairness } \\
\text { (officials) }\end{array}$ & $\begin{array}{l}\text { DV-10.3 } \\
\text { Fairness } \\
\text { (officials) }\end{array}$ & \multirow{10}{*}{ mean $r=0.73$} \\
\hline \multirow{3}{*}{$\begin{array}{l}\text { DV-10.1 Fairness } \\
\text { (officials) }\end{array}$} & Pearson Correlation & --- & --- & --- & \\
\hline & Sig. (2-tailed) & --- & --- & --- & \\
\hline & $\mathrm{N}$ & --- & --- & ---- & \\
\hline \multirow{3}{*}{$\begin{array}{l}\text { DV-10.2 Fairness } \\
\text { (officials) }\end{array}$} & Pearson Correlation & 0.730 & --- & --- & \\
\hline & Sig. (2-tailed) & 0.000 & --- & --- & \\
\hline & $\mathrm{N}$ & 87 & ---- & --- & \\
\hline \multirow{3}{*}{$\begin{array}{l}\text { DV-10.3 Fairness } \\
\text { (officials) }\end{array}$} & Pearson Correlation & 0.803 & 0.667 & --- & \\
\hline & Sig. (2-tailed) & 0.000 & 0.000 & --- & \\
\hline & $\mathrm{N}$ & 89 & 88 & --- & \\
\hline \multicolumn{2}{|c|}{ Commitment to Institution } & $\begin{array}{l}\mathrm{CV}-11.1 \\
\text { Commitment to } \\
\text { Institution }\end{array}$ & $\begin{array}{l}\text { CV-11.2 } \\
\text { Commitment to } \\
\text { Institution }\end{array}$ & & \\
\hline \multirow{3}{*}{$\begin{array}{l}\text { CV-11.1 Commitment } \\
\text { to Institution }\end{array}$} & Pearson Correlation & - & $\overline{----}$ & & \\
\hline & Sig. (2-tailed) & --- & ---- & & \\
\hline & $\mathrm{N}$ & --- & ---- & & \\
\hline \multirow{3}{*}{$\begin{array}{l}\text { CV-11.2 Commitment } \\
\text { to Institution }\end{array}$} & Pearson Correlation & 0.928 & --- & & \\
\hline & Sig. (2-tailed) & 0.000 & --- & & \\
\hline & $\mathrm{N}$ & 94 & --- & & \\
\hline
\end{tabular}




\section{Appendix D}

\section{Correlations between Control Variables}

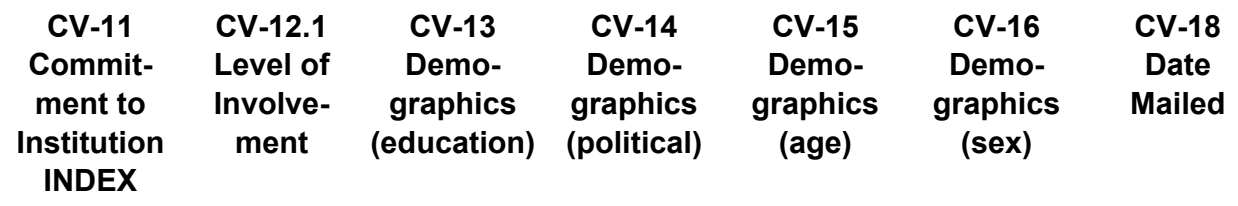

\begin{tabular}{|c|c|c|c|c|c|c|c|c|}
\hline CV-11 & Pearson Correlation & ---- & ---- & ---- & --- & ---- & ---- & ---- \\
\hline \multirow{2}{*}{$\begin{array}{l}\text { Commitment to } \\
\text { Institution INDEX }\end{array}$} & Sig. (2-tailed) & ---- & ---- & --- & --- & --- & --- & --- \\
\hline & $\mathrm{N}$ & ---- & --- & --- & ---- & ---- & --- & --- \\
\hline \multirow{3}{*}{$\begin{array}{l}\text { CV-12.1 Level of } \\
\text { Involvement }\end{array}$} & Pearson Correlation & 0.193 & ---- & --- & --- & --- & --- & --- \\
\hline & Sig. (2-tailed) & 0.062 & ---- & --- & --- & ---- & ---- & --- \\
\hline & $\mathrm{N}$ & 94 & ---- & --- & ---- & ---- & --- & ---- \\
\hline CV-13 & Pearson Correlation & 0.102 & -0.024 & --- & --- & ---- & ---- & --- \\
\hline \multirow{2}{*}{$\begin{array}{l}\text { Demographics } \\
\text { (education) }\end{array}$} & Sig. (2-tailed) & 0.336 & 0.820 & --- & ---- & --- & --- & --- \\
\hline & $\mathrm{N}$ & 91 & 93 & ---- & --- & --- & ---- & ---- \\
\hline CV-14 & Pearson Correlation & -0.102 & -0.006 & 0.283 & ---- & ---- & ---- & --- \\
\hline \multirow{2}{*}{$\begin{array}{l}\text { Demographics } \\
\text { (political) }\end{array}$} & Sig. (2-tailed) & 0.343 & 0.953 & 0.007 & ---- & ---- & ---- & --- \\
\hline & $\mathrm{N}$ & 89 & 91 & 89 & ---- & ---- & ---- & --- \\
\hline CV-15 & Pearson Correlation & 0.093 & 0.046 & 0.052 & -0.016 & --- & --- & --- \\
\hline \multirow{2}{*}{$\begin{array}{l}\text { Demographics } \\
\text { (age) }\end{array}$} & Sig. (2-tailed) & 0.373 & 0.654 & 0.621 & 0.878 & --- & --- & --- \\
\hline & $\mathrm{N}$ & 94 & 96 & 93 & 91 & ---- & --- & ---- \\
\hline CV-16 & Pearson Correlation & 0.108 & 0.147 & 0.029 & -0.121 & 0.223 & ---- & ---- \\
\hline \multirow{2}{*}{$\begin{array}{l}\text { Demographics } \\
\text { (sex) }\end{array}$} & Sig. (2-tailed) & 0.301 & 0.154 & 0.785 & 0.252 & 0.030 & ---- & --- \\
\hline & $\mathrm{N}$ & 93 & 95 & 93 & 91 & 95 & ---- & --- \\
\hline \multirow[t]{3}{*}{ CV-18 Date Mailed } & Pearson Correlation & -0.179 & -0.186 & -0.074 & -0.017 & 0.132 & 0.077 & --- \\
\hline & Sig. (2-tailed) & 0.084 & 0.070 & 0.481 & 0.870 & 0.199 & 0.459 & --- \\
\hline & $\mathrm{N}$ & 94 & 96 & 93 & 91 & 96 & 95 & ---- \\
\hline
\end{tabular}


Correlations between Control Variables \& Independent Variables

\begin{tabular}{|c|c|c|c|c|c|}
\hline $\begin{array}{c}\text { IV-2.1 } \\
\text { Outcome } \\
\text { Favorabilit } \\
\text { y } \\
\text { (absolute) }\end{array}$ & $\begin{array}{c}\text { IV-2.2 } \\
\text { Outcome } \\
\text { Favorabilit } \\
\text { y (relative) } \\
\text { INDEX }\end{array}$ & $\begin{array}{c}\text { IV-3 } \\
\text { Control } \\
\text { INDEX }\end{array}$ & $\begin{array}{c}\text { IV-4 } \\
\text { Neutrality } \\
\text { INDEX }\end{array}$ & $\begin{array}{c}\text { IV-5 } \\
\text { Trust } \\
\text { INDEX }\end{array}$ & $\begin{array}{c}\text { IV-6 } \\
\text { Standing } \\
\text { INDEX }\end{array}$ \\
\hline 0.786 & 0.552 & 0.728 & 0.778 & 0.895 & 0.862 \\
\hline 0.000 & 0.000 & 0.000 & 0.000 & 0.000 & 0.000 \\
\hline 91 & 91 & 93 & 92 & 92 & 93 \\
\hline 0.154 & -0.106 & 0.144 & 0.146 & 0.226 & 0.151 \\
\hline 0.142 & 0.311 & 0.163 & 0.160 & 0.028 & 0.145 \\
\hline 92 & 93 & 95 & 94 & 94 & 95 \\
\hline 0.086 & 0.064 & 0.003 & -0.002 & 0.118 & 0.186 \\
\hline 0.423 & 0.549 & 0.974 & 0.987 & 0.263 & 0.075 \\
\hline 90 & 91 & 92 & 92 & 92 & 93 \\
\hline-0.120 & -0.123 & -0.211 & -0.172 & -0.149 & -0.069 \\
\hline 0.264 & 0.250 & 0.045 & 0.105 & 0.162 & 0.514 \\
\hline 88 & 89 & 90 & 90 & 90 & 91 \\
\hline 0.164 & 0.207 & 0.075 & 0.076 & 0.168 & 0.049 \\
\hline 0.118 & 0.046 & 0.473 & 0.464 & 0.105 & 0.635 \\
\hline 92 & 93 & 95 & 94 & 94 & 95 \\
\hline 0.276 & 0.168 & 0.217 & 0.122 & 0.151 & 0.103 \\
\hline 0.008 & 0.107 & 0.036 & 0.241 & 0.145 & 0.321 \\
\hline 92 & 93 & 94 & 94 & 94 & 95 \\
\hline-0.083 & 0.020 & -0.018 & -0.040 & -0.096 & -0.120 \\
\hline 0.433 & 0.849 & 0.863 & 0.701 & 0.358 & 0.246 \\
\hline 92 & 93 & 95 & 94 & 94 & 95 \\
\hline
\end{tabular}

